Atmos. Chem. Phys., 13, 8991-9019, 2013

www.atmos-chem-phys.net/13/8991/2013/

doi:10.5194/acp-13-8991-2013

(c) Author(s) 2013. CC Attribution 3.0 License.

\title{
Presenting SAPUSS: Solving Aerosol Problem by Using Synergistic Strategies in Barcelona, Spain
}

\author{
M. Dall'Osto ${ }^{1,2,3, *}$, X. Querol ${ }^{1}$, A. Alastuey ${ }^{1}$, M. C. Minguillon $^{1}$, M. Alier ${ }^{1}$, F. Amato ${ }^{1}$, M. Brines ${ }^{1}$, M. Cusack ${ }^{1}$, \\ J. O. Grimalt ${ }^{1}$, A. Karanasiou ${ }^{1}$, T. Moreno ${ }^{1}$, M. Pandolfi ${ }^{1}$, J. Pey ${ }^{1}$, C. Reche $^{1}$, A. Ripoll ${ }^{1}$, R. Tauler ${ }^{1}$, \\ B. L. Van Drooge ${ }^{1}$, M. Viana ${ }^{1}$, R. M. Harrison ${ }^{2,16}$, J. Gietl ${ }^{2}$, D. Beddows ${ }^{2}$, W. Bloss ${ }^{2}$, C. O'Dowd ${ }^{3}$, D. Ceburnis ${ }^{3}$, \\ G. Martucci ${ }^{3}$, N. L. Ng ${ }^{4}$, D. Worsnop ${ }^{4}$, J. Wenger ${ }^{5}$, E. Mc Gillicuddy ${ }^{5}$, J. Sodeau ${ }^{5}$, R. Healy ${ }^{5}$, F. Lucarelli ${ }^{6}$, S. Nava ${ }^{6}$, \\ J. L. Jimenez ${ }^{7}$, F. Gomez Moreno ${ }^{8}$, B. Artinano ${ }^{8}$, A. S. H. Prévôt ${ }^{9}$, L. Pfaffenberger ${ }^{9}$, S. Frey ${ }^{10}$, F. Wilsenack ${ }^{11}$, \\ D. Casabona ${ }^{12}$, P. Jiménez-Guerrero ${ }^{13}$, D. Gross ${ }^{14}$, and N. Cots ${ }^{15}$ \\ ${ }^{1}$ IDAEA-CSIC, C/Jordi Girona 18-22, 08034 Barcelona, Spain \\ ${ }^{2}$ National Centre for Atmospheric Science, Division of Environmental Health \& Risk Management, University of \\ Birmingham, Birmingham, UK \\ ${ }^{3}$ School of Physics, Centre for Climate \& Air Pollution Studies, National University of Ireland Galway, University Road, \\ Galway, Ireland \\ ${ }^{4}$ Center for Aerosol and Cloud Chemistry, Aerodyne Research, Inc., Billerica, MA, USA \\ ${ }^{5}$ Department of Chemistry and Environmental Research Institute, University College Cork, Ireland \\ ${ }^{6}$ National Institute of Nuclear Physics (INFN) and Department of Physics and Astronomy, University of Florence, Sesto \\ Fiorentino, Italy \\ ${ }^{7}$ Dept. of Chemistry and Biochemistry, University of Colorado, Boulder, CO, USA \\ ${ }^{8}$ CIEMAT, Environment Department, Av. Complutense 40, 28040 Madrid, Spain \\ ${ }^{9}$ Paul Scherrer Institute, Laboratory of Atmospheric Chemistry, 5232 Villigen PSI, Switzerland \\ ${ }^{10}$ Jenoptik, Defense \& Civil Systems, Sensor Systems Business Unit, Teltow, Germany \\ ${ }^{11}$ Wehrwissenschaftliches Institut für Schutztechnologien, Munster, Germany \\ ${ }^{12}$ Area de Medi Ambient, Diputació de Barcelona, Barcelona, Spain \\ ${ }^{13}$ Física de la Tierra, Universidad de Murcia, Murcia, Spain \\ ${ }^{14}$ Department of Chemistry, Carleton College, MN, USA \\ ${ }^{15}$ Gencat, Direcció General de Qualitat Ambiental Av. Diagonal 523-525, 08029 Barcelona, Spain \\ ${ }^{16}$ Department of Environmental Sciences/Center of Excellence in Environmental Studies, King Abdulaziz University, Jeddah, \\ 21589, Saudi Arabia \\ *now at: Institut de Ciències del Mar, ICM-CSIC, Pg Marítim de la Barceloneta 37-49, 08003 Barcelona, Spain
}

Correspondence to: M. Dall'Osto (manuel.dallosto@gmail.com)

Received: 10 July 2012 - Published in Atmos. Chem. Phys. Discuss.: 31 July 2012

Revised: 15 July 2013 - Accepted: 16 July 2013 - Published: 9 September 2013

\begin{abstract}
This paper presents the summary of the key objectives, instrumentation and logistic details, goals, and initial scientific findings of the European Marie Curie Action SAPUSS project carried out in the western Mediterranean Basin (WMB) during September-October in autumn 2010. The key SAPUSS objective is to deduce aerosol source characteristics and to understand the atmospheric processes responsible for their generations and transformations - both
\end{abstract}

horizontally and vertically in the Mediterranean urban environment. In order to achieve so, the unique approach of SAPUSS is the concurrent measurements of aerosols with multiple techniques occurring simultaneously in six monitoring sites around the city of Barcelona (NE Spain): a main road traffic site, two urban background sites, a regional background site and two urban tower sites $(150 \mathrm{~m}$ and $545 \mathrm{~m}$ above sea level, $150 \mathrm{~m}$ and $80 \mathrm{~m}$ above ground, respectively). 
SAPUSS allows us to advance our knowledge sensibly of the atmospheric chemistry and physics of the urban Mediterranean environment. This is well achieved only because of both the three dimensional spatial scale and the high sampling time resolution used. During SAPUSS different meteorological regimes were encountered, including warm Saharan, cold Atlantic, wet European and stagnant regional ones. The different meteorology of such regimes is herein described. Additionally, we report the trends of the parameters regulated by air quality purposes (both gaseous and aerosol mass concentrations); and we also compare the six monitoring sites. High levels of traffic-related gaseous pollutants were measured at the urban ground level monitoring sites, whereas layers of tropospheric ozone were recorded at tower levels. Particularly, tower level night-time average ozone concentrations $\left(80 \pm 25 \mu \mathrm{g} \mathrm{m}^{-3}\right)$ were up to double compared to ground level ones. The examination of the vertical profiles clearly shows the predominant influence of $\mathrm{NO}_{\mathrm{x}}$ on ozone concentrations, and a source of ozone aloft. Analysis of the particulate matter (PM) mass concentrations shows an enhancement of coarse particles $\left(\mathrm{PM}_{2.5-10}\right)$ at the urban ground level $\left(+64 \%\right.$, average $\left.11.7 \mu \mathrm{g} \mathrm{m}^{-3}\right)$ but of fine ones $\left(\mathrm{PM}_{1}\right)$ at urban tower level $\left(+28 \%\right.$, average $\left.14.4 \mu \mathrm{g} \mathrm{m}^{-3}\right)$. These results show complex dynamics of the size-resolved PM mass at both horizontal and vertical levels of the study area. Preliminary modelling findings reveal an underestimation of the fine accumulation aerosols. In summary, this paper lays the foundation of SAPUSS, an integrated study of relevance to many other similar urban Mediterranean coastal environment sites.

\section{Introduction}

Atmospheric particles have several adverse effects on human health (Pope and Dockery, 2006) and atmospheric visibility, and partly compensate climate forcing by greenhouse gases (IPCC, 2007). These effects depend on particle diameter and chemical composition, as well as on mass and number concentrations which exhibit large temporal and spatial variability. Indeed, aerosols have multiple sources, and emissions from the same source will change with time and operating conditions. In other words, since particles undergo a variety of physical and chemical transformations in the atmosphere, what is measured at the source may not be what will be found in the atmosphere. A detailed knowledge of the chemical composition of particles - alongside knowledge of their size and concentration - is important to apportion the sources of PM in the atmosphere.

Unfortunately, a major complexity associated with PM involves its measurement. Airborne particles come in sizes ranging over five orders of magnitude from $2 \mathrm{~nm}$ to larger than $100 \mu \mathrm{m}$, and contain thousands of chemical compounds. Broadly, there are two general approaches to making atmo- spheric measurements: remote sensing and in situ. In the former one, some atmospheric parameters of interest are derived indirectly by the changes in atmospheric radiation that result from the presence of the parameter (Pandolfi et al., 2013). By contrast, the latter in situ measurements involve the direct sampling of the atmosphere (McMurry, 2000). Whilst the technology to count, size, and determine the mass concentration of particles in real time accurately is fairly well established, the chemical analysis of aerosols is not as easily performed (McMurry, 2000). Off-line aerosol measurements (particulate matter collection on a filter or impactor substrate over a period of hours) carry many intrinsic limitations: generally low temporal resolution, evaporation or loss of volatile components, reaction of chemically unstable compounds and interchange with the gas phase during sampling. In other words, off-line aerosol techniques do provide very valuable quantitative information on several chemical compounds, but the low time resolution of most of them often does not allow extracting any information on the formation and the evolution of processes happening in the atmosphere. However, Mass Spectrometry of Atmospheric Aerosol (MSAA) has recently been established and has quickly become the most essential and fastest growing area of aerosol research (Laskin et al., 2012). On-line MSAA techniques allow the simultaneous measurement of particle composition, as well as size, high temporal resolution, and ability to distinguish between internally and externally mixed particle components (Pratt and Prather, 2011a, b). In summary, an array of instruments is required to get close to the full picture of the source identification and evolution (aging) of particles in the atmosphere.

Additional complexity in understanding the atmospheric and chemistry processes of the aerosols comes from the location of the aerosol measurements. The study area often reflects the objectives of the research programme, which usually needs to target both source-oriented measurement sites and background locations. Furthermore, such aerosol sampling sites can be located in complex terrain where major meteorological factors determine the concentrations of air pollutants. This is the case for example of coastal urban areas in the Mediterranean region (see details in Sect. 2).

In conclusion, a number of ad hoc instruments have to be deployed simultaneously in a number of key locations. The objective of this paper is to present SAPUSS, a Marie Curie Action (FP7-PEOPLE-2009-IEF-254773) which fundamentally aims to synergistically deploy a number of state-of-theart aerosol measurements techniques which will result in significant advances in our knowledge of atmospheric aerosol properties. State-of-the-art real time aerosol techniques have not been widely deployed in the western Mediterranean Basin (WMB) areas although it is worth mentioning that recently the DAURE (Determination of the sources of atmospheric Aerosols in Urban and Rural Environments in the western Mediterranean) project was carried out in the same area (Minguillón et al., 2011; Mohr et al., 2012). The original SAPUSS proposal was extensively expanded due a large 
Table 1. Institutions taking part in SAPUSS.

\begin{tabular}{|c|c|c|c|}
\hline & Institution & Country & Involvement \\
\hline 1 & $\begin{array}{l}\text { Institute of Environmental Assessment } \\
\text { and Water Research (IDÆA), CSIC }\end{array}$ & ES & $\begin{array}{l}\text { Project PI, on line and off line } \\
\text { sampling collection and analy- } \\
\text { sis of atmospheric pollutants }\end{array}$ \\
\hline 2 & $\begin{array}{l}\text { Division of Environmental Health \& } \\
\text { Risk Management, University of Birm- } \\
\text { ingham }\end{array}$ & UK & ATOFMS, CPC, MOUDI \\
\hline 3 & $\begin{array}{l}\text { School of Physics \& Centre for Climate } \\
\text { and Air Pollution Studies, University of } \\
\text { Galway }\end{array}$ & IR & Ceilometer, AMS \\
\hline 4 & Aerodyne Inc & USA & AMS \\
\hline 5 & $\begin{array}{l}\text { Centre for Research into Atmospheric } \\
\text { Chemistry, University of Cork }\end{array}$ & IR & ATOFMS \\
\hline 6 & $\begin{array}{l}\text { Department of Physics and Astronomy, } \\
\text { University of Florence }\end{array}$ & IT & PIXE \\
\hline 7 & $\begin{array}{l}\text { Dept. of Chem. \& Biochem. \& CIRES } \\
\text { Fellow } \\
\text { University of Colorado }\end{array}$ & USA & AMS \\
\hline 8 & $\begin{array}{l}\text { Contaminación Atmosférica, Departa- } \\
\text { mento de Medio Ambiente, CIEMAT }\end{array}$ & ES & SMPS, CPC \\
\hline 9 & $\begin{array}{l}\text { Laboratory of Atmospheric Chemistry, } \\
\text { PSI }\end{array}$ & $\mathrm{CH}$ & AMS \\
\hline 10 & Jenoptik, Defense \& Civil Systems & $\mathrm{DE}$ & Ceilometer \\
\hline 11 & $\begin{array}{l}\text { Wehrwissenschaftliches Institut für } \\
\text { Schutztechnologien }\end{array}$ & $\mathrm{DE}$ & Ceilometer \\
\hline 12 & $\begin{array}{l}\text { Area de Medi Ambient, Diputació de } \\
\text { Barcelona }\end{array}$ & ES & local support \\
\hline 13 & $\begin{array}{l}\text { Department of Physics, Physics of the } \\
\text { Earth, University of Murcia }\end{array}$ & ES & modelling \\
\hline 14 & $\begin{array}{l}\text { Department of Chemistry, Carleton } \\
\text { College }\end{array}$ & USA & Instrument support \\
\hline 15 & Gencat & ES & Local support \\
\hline
\end{tabular}

number of research groups willing to take part (Table 1). SAPUSS has generated about one dozen research manuscripts, which can be found in this ACP SAPUSS special issue. This introductory paper aims to overview the sampling campaign which took part mainly in Barcelona (Spain) between 20 September and 20 October 2010 (local time, UTC+2). Whilst all the SAPUSS scientific findings will be reviewed in a final summarizing manuscript, we feel the complexity of the SAPUSS field study (six monitoring sites and the large number of instruments used) requires an introduction in this ACP special issue. However, in this overview paper, we not present only the SAPUSS project, but also consider- ations about the meteorology encountered. Special emphasis is also given in presenting and discussing both gaseous concentrations and particulate mass concentrations simultaneously monitored at different monitoring sites.

The main SAPUSS scientific objectives were as follows:

- To interpret the variability of aerosol levels and composition in the urban Mediterranean environment of Barcelona, the second largest city in Spain and a major metropolitan agglomerate in Europe.

- To study in detail the processes of formation and transformation of aerosols in the urban background and road site atmospheric environment. 
- To elucidate the fate of freshly generated traffic particles at different elevations within the urban boundary layer.

- To examine the spatial scales of urban nucleation events and variations in ultrafine aerosol particle characteristics in locations with differing land use and emission profiles, to examine the meteorological context for nucleation events, to provide number concentrations and ultrafine aerosol particle composition during nucleation events.

- To understand the physical and chemical properties of the urban aerosols detected at ground level (road and urban background sites) and above the city (2 towers).

- To study aerosol particle size distributions in terms of the sources and the physico-chemical transformations occurring simultaneously at the road, background, tower and regional background sites.

- To study the structure of the atmospheric boundary layer and the influence of boundary layer vertical structure upon air pollution processes, especially in the context of diurnal changes.

- To quantify the contribution of both exhaust- and nonexhaust-traffic-generated particles in the road site relative to the urban background one.

- To apply receptor modelling to organic and inorganic species, as well as physical properties such as particle number and aerosol size distributions in order to allow the identification of emission sources and their respective contributions to the PM mass in ambient air.

Our unique measurement approach involved the deployment of a large number of instruments at six monitoring sites (as summarized in Table 2, and described in detail in Sect. 2), allowing the following:

- Simultaneous measurements of gaseous pollutants and local meteorological parameters.

- Simultaneous measurements of the vertical and horizontal aerosol profiles from two ceilometers.

- Simultaneous measurements of hourly $\mathrm{PM}_{1}, \mathrm{PM}_{2.5}$ and $\mathrm{PM}_{10}$ aerosol mass concentrations at six sites to study the vertical and horizontal aerosol mass distributions (six optical counters).

- Simultaneous measurements of size-resolved particle number concentrations by deploying 4 differential mobility analysers - DMAs - and 11 condensation particle counters - CPCs - (4 scanning mobility particle sizers - SMPSs - and 7 single CPCs altogether).
- Simultaneous measurements of inorganic and organic components of the $\mathrm{PM}_{1}, \mathrm{PM}_{2.5}$ and $\mathrm{PM}_{10}$ aerosol mass loadings at different sites (10 high-volume samplers altogether).

- Simultaneous measurements of co-located highly time-resolved instruments (black carbon, ATOFMS, HR-ToF-AMS and streaker samples) in order to identify unique sources which would not be possible without multiple highly resolved instruments working in concert. Two super sites are used (urban background and road site) where simultaneously non-refractory and refractory aerosol species at hourly concentrations are obtained, as well as single particle chemical composition information in real time.

Additional advantages can be obtained when data from suites of instruments are further combined with atmospheric models. Among the receptor-oriented models, chemical mass balance $(\mathrm{CMB})$, positive matrix factorization $(\mathrm{PMF})$, principal component analysis (PCA) and multi-linear engine (ME) are widely used to evaluate the effects of the source emissions. The joint on-line and off-line data generated from SAPUSS can be the input of the receptor-oriented models, which will help to re-construct the impacts of emissions from different sources of atmospheric pollutants such as PM. In particular the hourly data series for inorganic refractory constituents obtained with the streaker samples, those from colocated AMS-ATOFMS measurements, and BC, CPC and aerosols size distributions measurements can constitute a unique ground-breaking basis for the application of source receptor modelling at hourly resolution.

\section{Study area and monitoring sites}

The SAPUSS campaign was carried out mainly in Barcelona, a large coastal urban agglomerate located in the WMB in the north-east (NE) part of Spain. The Mediterranean region (MR) lies in a transition zone between the arid climate of North Africa and the temperate and rainy climate of central Europe. This region is often exposed to multiple environmental stresses, such as a simultaneous water shortage and air pollution exposure (IPCC, 2007). Unique large gradients in aerosol mass (Putaud et al., 2010) and number concentrations (Reche et al., 2011) are indeed observed when moving from north-east Europe to the MR. In contrast to central and northern Europe, at Mediterranean latitudes photochemical pollution episodes can also occur during winter since solar radiation is intensive all year round, driving photochemical reactions that change the nature of air pollution (Koulouri et al., 2008; Velchev et al., 2011). The Mediterranean area is rich of aromatic plants with high emissions of biogenic volatile organic compounds and the photochemical activity that transforms these compounds into aerosol is high (Kesselmeier and Staudt, 1999). Additionally, high 
Table 2. Summary of measurements taken during SAPUSS.

\begin{tabular}{|c|c|c|c|c|c|c|c|c|}
\hline $\begin{array}{l}\text { Properties } \\
\text { measured }\end{array}$ & $\begin{array}{l}\text { Specific properties } \\
\text { measured }\end{array}$ & $\begin{array}{l}\text { Analytical } \\
\text { technique }\end{array}$ & $\begin{array}{l}\text { Temporal } \\
\text { resolution }\end{array}$ & RS & UB & $\mathrm{TM}$ & $\mathrm{TC}\left({ }^{\#}=\mathrm{TCg}\right)$ & $\mathrm{RB}$ \\
\hline \multirow[t]{5}{*}{ Meteorology } & WD & Standard & $1 \mathrm{~h}$ & $\mathrm{~V}$ & $\mathrm{~V}$ & $\mathrm{~V}$ & $\mathrm{~V}$ & $\mathrm{~V}$ \\
\hline & WS & Standard & $1 \mathrm{~h}$ & $\mathrm{~V}$ & $\mathrm{~V}$ & $\mathrm{~V}$ & $\mathrm{~V}$ & $\mathrm{~V}$ \\
\hline & $T$ & Standard & $1 \mathrm{~h}$ & $\mathrm{~V}$ & $\mathrm{~V}$ & $\mathrm{~V}$ & $\mathrm{~V}$ & $\mathrm{~V}$ \\
\hline & $\mathrm{RH}$ & Standard & $1 \mathrm{~h}$ & $\mathrm{~V}$ & $\mathrm{~V}$ & $\mathrm{~V}$ & $\mathrm{~V}$ & $\mathrm{~V}$ \\
\hline & Radiation & Standard & $1 \mathrm{~h}$ & $\mathrm{~V}$ & $\mathrm{~V}$ & $\mathrm{~V}$ & $\mathrm{~V}$ & $\mathrm{~V}$ \\
\hline \multirow{2}{*}{$\begin{array}{l}\text { Remote sensing and } \\
\text { boundary layer }\end{array}$} & boundary layer & Radiosounding & $12 \mathrm{~h}$ & & $\mathrm{~V}$ & & & \\
\hline & & Ceilometer CHM $15 \mathrm{~K}$ & $1 \mathrm{~h}$ & & V (horizontal) & & $\mathrm{V}^{\#}$ (vertical) & \\
\hline \multirow[t]{5}{*}{ Gaseous pollutants } & $\mathrm{CO}$ & IR absorption & $30 \mathrm{~min}$ & $\mathrm{~V}$ & $\mathrm{~V}$ & & $\mathrm{~V}^{\#}$ & $\mathrm{~V}$ \\
\hline & NO & Chemiluminescence & $30 \min$ & $\mathrm{V}$ & $\mathrm{V}$ & & $\mathrm{V}^{\#}$ & $\mathrm{~V}$ \\
\hline & $\mathrm{NO}_{2}$ & Chemiluminescence & $30 \mathrm{~min}$ & $\mathrm{~V}$ & $\mathrm{~V}$ & & $\mathrm{~V}^{\#}$ & $\mathrm{~V}$ \\
\hline & $\mathrm{SO}_{2}$ & UV fluorescence & $30 \mathrm{~min}$ & $\mathrm{~V}$ & $\mathrm{~V}$ & & $\mathrm{~V}^{\#}$ & $\mathrm{~V}$ \\
\hline & $\mathrm{O}_{3}$ & UV absorption & $30 \mathrm{~min}$ & $\mathrm{~V}$ & $\mathrm{~V}$ & & $\mathrm{~V}^{\#}$ & $\mathrm{~V}$ \\
\hline \multirow{5}{*}{$\begin{array}{l}\text { Aerosol mass } \\
\text { loading }\end{array}$} & & Impactor MOUDI & 72 & $\mathrm{~V}$ & & & & \\
\hline & & $\mathrm{PM}_{1}$ Grav. & 12 & $\mathrm{~V}$ & $\mathrm{~V}$ & & & $\mathrm{~V}$ \\
\hline & & $\mathrm{PM}_{2.5}$ Grav. & 24 & $\mathrm{~V}$ & $\mathrm{~V}$ & & & \\
\hline & & $\mathrm{PM}_{10}$ Grav. & 12 & $\mathrm{~V}$ & $\mathrm{~V}$ & $\mathrm{~V}$ & $\mathrm{~V}$ & $\mathrm{~V}$ \\
\hline & & Grim & $1 \mathrm{~h}$ & $\mathrm{~V}$ & $\mathrm{~V}$ & $\mathrm{~V}$ & $\begin{array}{l}\mathrm{V}, \mathrm{V}^{\#} \text { (both TC } \\
\text { and Fabra) }\end{array}$ & $\mathrm{V}$ \\
\hline \multirow{3}{*}{$\begin{array}{l}\text { Real time aerosol } \\
\text { mass spectrometry }\end{array}$} & & AMS & $10 \mathrm{~min}$ & V (HR-ToF-AMS) & V (HR-ToF-AMS) & & & \\
\hline & & ATOFMS & real time & V (TSI 3800-030) & V (TSI 3800-100) & & & \\
\hline & & PIXE & $1 \mathrm{~h}$ & $\mathrm{~V}$ & $\mathrm{~V}$ & & & \\
\hline Black carbon & & MAAP-Aethalometer & $10 \mathrm{~min}$ & V (MAAP) & V (MAAP) & $\begin{array}{l}\text { V (Magee AE-21 } \\
\text { Aethalometer) }\end{array}$ & V (MAAP) & V (MAAP) \\
\hline \multirow{2}{*}{$\begin{array}{l}\text { Particle number } \\
\text { concentration }\end{array}$} & $(>3 \mathrm{~nm})$ & $\mathrm{CPC}$ & $1 \mathrm{~m}$ & & & V (TSI 3025) & V (TSI WB3786) & \\
\hline & $(>5-7 \mathrm{~nm})$ & $\mathrm{CPC}$ & $1 \mathrm{~m}$ & V (TSI 3022) & V (TSI WB 3785) & V (TSI 3022) & V (TSI 3022) & V (TSI WB 3785) \\
\hline \multirow{2}{*}{$\begin{array}{l}\text { Aerosol size } \\
\text { resolved }\end{array}$} & $15-600 \mathrm{~nm}$ & SMPS & $5 \mathrm{~min}$ & $\mathrm{~V}$ (TSI 3080 & $\mathrm{~V}$ (TSI 3080 & & $\mathrm{~V}^{\#}$ (TSI 3034 & V (EUSAAR_IFT \\
\hline & & & & + СРC 3010) & + CPC 3775$)$ & & CPC built-in) & with CPC 3772) \\
\hline \multirow[t]{4}{*}{ Chemical analysis } & Metals & ICP-MS, ICP-AES & $12 / 24 \mathrm{~h}$ & $\mathrm{~V}$ & $\mathrm{~V}$ & $\mathrm{~V}$ & $\mathrm{~V}$ & $\mathrm{~V}$ \\
\hline & EC-OC & Sunset & $12 / 24 \mathrm{~h}$ & $\mathrm{~V}$ & $\mathrm{~V}$ & $\mathrm{~V}$ & $\mathrm{~V}$ & $\mathrm{~V}$ \\
\hline & Organic speciation & GC-MS & $Æ 12 / 24 \mathrm{~h}$ & $\mathrm{~V}$ & $\mathrm{~V}$ & $\mathrm{~V}$ & $\mathrm{~V}$ & $\mathrm{~V}$ \\
\hline & Inorganic species & IC & $12 / 24 \mathrm{~h}$ & $\mathrm{~V}$ & $\mathrm{~V}$ & $\mathrm{~V}$ & $\mathrm{~V}$ & $\mathrm{~V}$ \\
\hline
\end{tabular}

contribution of mineral aerosol dust (both from nearby Saharan region and anthropogenic sources) of most urban sites of southern Europe may cause exceedances of the air quality standards (Querol et al., 2001a, 2009). As an overall result, several urban areas in southern Europe are not capable of meeting the implemented EU standards for air pollution. It is also important to remember that this study region suffers from a lack of real time atmospheric measurements (Kulmala et al., 2011).

Within the Mediterranean area, the WMB possesses peculiar and complex atmospheric dynamics affecting synoptic, regional and local meteorological processes: (1) the influence of the Azores high-pressure system in the meteorology of the Iberian Peninsula (IP); (2) the coastal ranges surrounding the Mediterranean coast; (3) the influence of the Iberian and Saharan thermal lows causing weak pressure gradients over the Mediterranean; (4) the intense breeze action along the Mediterranean coast favoured by the prevailing low advective conditions; (5) the scarce summer precipitation; and (6) the intense seasonal contrast concerning temperature, humidity and rainfall (Millan et al., 1997; Soriano et al., 2001; Rodriguez et al., 2002, 2003; Jorba et al., 2004).

As a result, a number of comparative studies on the variability of PM levels and the composition along the WMB report high atmospheric aerosol loadings (e.g. Querol et al., 2001b, 2009; Viana et al., 2008; Kocak et al., 2008). It is worth mentioning that eastern Mediterranean countries also show high levels of atmospheric PM compared to northern and some central European regions (Kanakidou et al., 2011).

Within the WMB, the city of Barcelona is confined within a coastal region characterized by a complex terrain (Fig. 1a). Main features of the area under study include (1) the coastal depression which contains most of the cities in the Barcelona Metropolitan Area in the $8 \mathrm{~km}$ strip of land between the sea and the first mountain range; (2) the coastal mountain range with main peaks around 500-650 m (Collserola Hills, Fig. 1); (3) the pre-coastal depression between the mountain coastal ranges; and (4) the pre-coastal mountain range where the regional background (RB) station is located (Fig. 1).

With a population of about 1.7 million inhabitants in the city and around 4 million in the metropolitan area, Barcelona is the fifth most populated metropolitan area in Europe. The urban architecture and dynamism around Barcelona city account for the very high population density in Europe (about 16000 inhabitants $\mathrm{km}^{-2}$ ); reflected also in the very high road traffic density $\left(6100\right.$ cars $\mathrm{km}^{2}$, much more than in most European cities with about $1000-1500$ cars $\mathrm{km}^{2}$; Amato et al., 2009; Reche et al., 2011). Additionally, Barcelona has one of the main harbours in the Mediterranean Basin, with the highest number of cruise ships for tourists in Spain. Furthermore, 




Fig. 1. (a-c) Maps of measurement sites used in SAPUSS: road site (RS), urban background (UB), Torre Mapfre (TM), Torre de Collserola (TC), Fabra observatory (TCg) and regional Montseny background site (RB).

several industrial zones, power plants, and important highways cross the area in all directions. In this situation, anthro- pogenic emissions are of a high importance and make this region one of the most polluted in the WMB.

A key feature of the SAPUSS study is the number of monitoring sites used, six in total: super site road site (RS), super site urban background (UB), site Torre Mapfre (TM), site Torre de Collserola (tower and ground urban background TC and $\mathrm{TCg}$, respectively), and site regional background (RB) (Fig. 1). This unique approach allows us to monitor simultaneously a large spatial area, both horizontally and vertically. RS and UB were named "super sites" as a large variety of instruments were deployed relative to the remaining sites. Table 2 shows the list of the instruments deployed during the SAPUSS field study, and the six monitoring sites are described in the sections below.

\subsection{Super site road site (RS)}

The RS site $\left(41^{\circ} 23^{\prime} 18^{\prime \prime} \mathrm{N}, 02^{\circ} 09^{\prime} 0^{\prime \prime} \mathrm{E}\right.$, Fig. 1) was situated in the car park of the Escuela de Ingeniería Técnica Industría (St. Urgell, 187 - elevation $40 \mathrm{~m}$ a.s.1.). Most instruments were located inside three vans parked about $4 \mathrm{~m}$ from the kerb. Air was drawn from outside the instruments throughout a number of home-designed inlets, situated on the vans' roofs at a height of about $4 \mathrm{~m}$ above ground with $1 / 4$ inch stainless steel tube led inside each trailer (length about $2 \mathrm{~m}$ ) to a manifold. Other off-line instruments were directly measuring aerosol properties without deploying any inlets.

Some light trees, a fence and a $2 \mathrm{~m}$ wide pedestrian path separate the road from the monitoring instruments. The road - which cuts the city from south-east to north-west - is a street canyon composed of a two-way cycling path and a oneway four-lane vehicle road. Figure $2 \mathrm{a}$ shows the vehicle intensity during the month of measurements, with an hourly average intensity of $690 \pm 370$ vehicles (about 17000 vehicles per day), reaching up to $1050 \pm 420$ vehicles per hour during traffic rush hour (Fig. 2b). A subway entrance is located on the right side of the RS, whereas shops and restaurants can be found opposite the RS. Two traffic lights are located about 50 and $150 \mathrm{~m}$ away from the RS, on the right and left side, respectively.

\subsection{Super site urban background site (UB)}

The UB measurement site $\left(41^{\circ} 23^{\prime} 15^{\prime \prime} \mathrm{N}, 02^{\circ} 07^{\prime} 05^{\prime \prime} \mathrm{E}\right.$, Fig. 1) was situated at the north-western periphery of the city centre in a small park (elevation $80 \mathrm{~m}$ a.s.l.). It is mainly surrounded by residential areas, and it is situated about $6 \mathrm{~km}$ from the sea (Fig. 1). Two trailers were deployed for housing the instruments at the UB, and the inlets (like the ones described for the RS site) were also situated on the roof of the two trailers at about $4 \mathrm{~m}$ above ground. It is important to remember that at a distance of about $300 \mathrm{~m}$ from the UB is Avenida Diagonal, one of Barcelona's broadest and most important avenues (nine vehicle lanes in total). During the SAPUSS field study, the hourly average vehicle 




(a)



Fig. 2. (a) Average hourly number of vehicles per day at Road Urgell (road RS site) and at Avenida Diagonal (close to the UB) and 2 (b) Diurnal traffic intensity and traffic occupation at the RS site and at Avenida Diagonal (UB).

intensity was $2560 \pm 1300$ (62 000 vehicles per day), going up to $5100 \pm 1700$ during the 08:00 UTC traffic rush hour peak. Note that the vehicle intensity (Fig. 2a) and the occupancy (Fig. 2b) of this main road present strong peaks at 08:00 UTC (07:00-09:00 UTC) and 18:00 UTC (17:0020:00 UTC). This diurnal variation is different from the one of the road next to the RS site, and the reason is due to the fact that whilst the Avenida Diagonal is mainly used for commuting in and out the city during the day, the road next to the RS (St. Urgell) reflects more the commercial traffic activity of the urban city centre.

\subsection{Torre Mapfre site (TM)}

Named after its owner, Torre Mapfre $\left(41^{\circ} 23^{\prime} 16^{\prime \prime} \mathrm{N}\right.$, $2^{\circ} 11^{\prime} 51^{\prime \prime}$ E, Fig. 1) is a skyscraper in the Olympic Port, the maritime neighbourhood of the old city of Barcelona. This tower holds the title for highest helipad in Spain at $154 \mathrm{~m}$ above ground ( $154 \mathrm{~m}$ a.s.l.). It is located about $200 \mathrm{~m}$ from the sea, with a small marina, a dock or basin with moorings and supplies for yachts and small boats in the south-east corner. The south-west corner instead is characterized by a wellknown Barcelona recreational area. By contrast, in the north side of the tower the ring road motorway B-10 (Ronda del Litoral) can be found, a two-lane two-way road (four lanes in total). The B-10 is tunnelled about $250 \mathrm{~m}$ before and after the tower $(0.5 \mathrm{~km}$ in total). Powerful air ventilators constantly renew the air and maintain the air quality within the tunnel motorway, and the extraction of the exhaust fumes is located next to the TM. Adjacent to the B-10, two additional threelane roads can be found at ground level (above the tunnelled B-10). Aerosol measurements were taken at the top floor of the tower ( $150 \mathrm{~m}$ a.s.l.). Instruments were deployed on the terrace of the tower, whereas some of the instruments were stored inside a room at the top floor (with $0.5 \mathrm{~m} \mathrm{1/4}$ inch copper pipe linked to the outside).

\subsection{Torre de Collserola sites (TC and TCg)}

Collserola is a mountain range (Tibidabo being the tallest peak, at $512 \mathrm{~m}$ ) between the Besòs and Llobregat rivers (Fig. 1). It is part of the Catalan Coastal Range, and such mountains separate Barcelona from the Vallès plain (pre-coastal depression). The area is preserved as a park (Collserola Park, $84.65 \mathrm{~km}^{2}$ ) and is the largest metropolitan park in the world. On the Vilana hill stands the Torre de Collserola (Collserola Tower, $41^{\circ} 25^{\prime} 02^{\prime \prime} \mathrm{N}, 02^{\circ} 06^{\prime} 51^{\prime \prime} \mathrm{E}$, Fig. 1), the main telecommunications tower of Barcelona. The tower is located at $445 \mathrm{~m}$ a.s.l., and measurements were taken on the fourth floor of this tower, at $80 \mathrm{~m}$ above ground level $(525 \mathrm{~m}$ a.s.1.). Instruments were kept inside a room, and short inlets $(<1 \mathrm{~m} \mathrm{1/4-inch} \mathrm{copper} \mathrm{pipe)} \mathrm{were} \mathrm{used} \mathrm{to}$ sample ambient air. Due to logistical reasons at the TC site (limited access and storage space), the Fabra Observatory $\left(41^{\circ} 25^{\prime} 56^{\prime \prime} \mathrm{N}, 2^{\circ} 07^{\prime} 27^{\prime \prime} \mathrm{E}\right)$ was also used as a monitoring site during the SAPUSS project. The Fabra Observatory is an astronomical observatory at $415 \mathrm{~m}$ elevation above sea level, and located about $450 \mathrm{~m}$ ( $900 \mathrm{~m}$ road distance) from the TC site. In summary, measurements were taken at ground level (TCg, $10 \mathrm{~m}$ above ground, $425 \mathrm{~m}$ a.s.l.) and at tower level (TC, $80 \mathrm{~m}$ above ground, $525 \mathrm{~m}$ a.s.1.). It is important to note that whilst TM is well within the Barcelona urban city centre, TC is located in the hills of the urban background of Barcelona. It is worthwhile to stress that the two monitoring towers are the tallest buildings within several kilometres of the sites (Fig. 1), with good exposure to winds from all directions.

\subsection{Montseny regional background site (RB)}

The Montseny site $\left(41^{\circ} 46^{\prime} 45^{\prime \prime} \mathrm{N}, 02^{\circ} 21^{\prime} 29^{\prime \prime} \mathrm{E}\right.$, Fig. 1) is part of the EUSAAR network (European Supersites for Atmospheric Aerosol Research, abbreviation "MSY"). The RB monitoring site is located within a regional natural park at about $50 \mathrm{~km}$ to the north-north-east side of the city of Barcelona and about $30 \mathrm{~km}$ from the Mediterranean coast. The Montseny natural park has the highest mountains in the area south of the Pyrenees and dominates the plains south of Girona. A detailed description of the measurement sites and previous measurement of aerosol concentration and composition can be found in the literature for the MSY station (Pey et al., 2010). 


\section{Description of measurements taken during SAPUSS}

\subsection{Physical properties}

\subsubsection{Meteorological parameters}

Meteorological variables (atmospheric pressure, wind speed - WS, wind direction - WD, solar radiation, temperature and relative humidity $-\mathrm{RH}$ ) were recorded at five SAPUSS monitoring sites (all excluding TC) during the whole field study. Data for RS, TM, TCg and RB were obtained from instruments located within the monitoring sites, whereas data for UB were obtained from a close meteorological station (100 m distant from our UB measurement site) located on the roof terrace of the Chemical and Physical Sciences Faculty of Barcelona University.

Some meteorological data were compromised: data from the TM site, which was under the shadow of the top part of the tower in the afternoon (affecting the solar radiation, the RH and the temperature values); and wind data from the RS site, which were affected by the street canyon conditions found at the road site (although representative of a typical road in Barcelona).

\subsubsection{Remote sensing measurements}

The structure of the planetary boundary layer (PBL) above Barcelona was monitored by simultaneous measurements of two Jenoptik CHM15K lidar ceilometers (Heese et al., 2010; Martucci et al., 2010) with $1064 \mathrm{~nm}$ wavelength and $15 \mathrm{~km}$ vertical range. The first ceilometer was deployed vertically, and it was located in the south-west part of Barcelona, on the roof terrace ( $8 \mathrm{~m}$ above ground) of the Institute of Earth Sciences Jaume Almera (Consejo Superior de Investigaciones Cientificas: CSIC), about $300 \mathrm{~m}$ south of the UB site. The second ceilometer was deployed horizontally on the terrace of the Fabra Observatory, looking at the Torre Mapfre (TCg, TM, Fig. 1). It is important to remember that the vertical profiles of atmospheric temperature, pressure and relative humidity as well as wind components were also obtained by radiosoundings performed twice per day (at 12:00 UTC and 00:00 UTC) at the UB site. Further information on the continuous atmospheric boundary layer observations during SAPUSS can be found elsewhere in this special issue (Pandolfi et al., 2013).

\subsubsection{Particle number and mass concentrations}

Total particle number concentrations were measured at five SAPUSS monitoring sites (RS, TM, TC, RS, UB). The same type of CPC particle counter (TSI CPC Model 3022A; lower $50 \%$ cut-point $7 \mathrm{~nm}$ ) was simultaneously deployed at the RS, TM, TC sites, whilst the instruments at the RB and UB sites were TSI water-based (WB) CPCs 3785 (with a lower 50\% cut-point at $5 \mathrm{~nm}$ ), which would lead to slightly higher readings relative to the Model 3022A instrument (Table 2). In- struments were intercompared before and after the campaign, giving excellent overlaps, with uncertainty of about $5 \%$ both before and after the campaign. Nano-CPCs (TSI 3025 and TSI WB 3786, $50 \%$ cut-point at $3 \mathrm{~nm}$ ) were also partially available during the SAPUSS project (Table 2). A number of different SMPS systems were deployed simultaneously at 4 different sites (RS, UB, TCg, RB, Table 2), providing sizeresolved aerosol particle number concentrations. Further information on the temporal and spatial evolution of ultrafine particles during SAPUSS can also be found elsewhere in this special issue (Dall'Osto et al., 2012, 2013a).

Aerosol mass loadings were determined both gravimetrically and by using real time optical counters. As regard for gravimetric measurements, high volume samplers DIGITEL DHA-80 and MCV CAV-A/Mmb $\left(30 \mathrm{~m}^{3} \mathrm{~h}^{-1}\right)$ equipped with $\mathrm{PM}_{1}$ or $\mathrm{PM}_{10}$ heads collected $12 \mathrm{~h}$ samples (from 11:00 UTC to 23:00 UTC and from 23:00 UTC to 11:00 UTC, local time) on quartz fibre filters (Pallflex 2500QAT-UP). PM $_{10}$ samples were collected at five SAPUSS sites (RS, UB, TCg, TM, $\mathrm{RB}$ ), whereas $\mathrm{PM}_{1}$ samples were collected only at RS, UB and $\mathrm{RB}$ sites, and $24 \mathrm{~h} \mathrm{PM}_{2.5}$ samples were collected at the UB and RS site. The total number of high volume samples collecting PM during the SAPUSS was 10 (Table 2). The gravimetric mass concentrations were corrected to account for humidity saturation on the filter. $\mathrm{PM}_{10}, \mathrm{PM}_{2.5}$ and $\mathrm{PM}_{1}$ concentrations were also continuously measured by means of optical counters (Grimm Labortechnik GmbH \& Co. KG; model 1107). The different instruments were intercompared before the campaign. The Grimm $\mathrm{PM}_{\mathrm{x}}$ concentrations were also corrected with the corrected gravimetric PM concentrations.

\subsection{Chemical properties}

\subsubsection{Real time (on-line) techniques}

Black carbon mass was derived by aerosol absorption using both a MaGee Scientific Scientific Aethalometer AE-16 (Aet.) and a multi-angle absorption photometer (MAAP). A total of four MAAP instruments were deployed during the SAPUSS (RS, UB, TC, RB, Table 2), whereas an Aethalometer was deployed at the TM site. MAAP instruments gave excellent agreement between them $( \pm 5 \%)$. The MAAPs and the Aethalometer were inter-compared before and after the field study, also giving excellent agreement (fitting: Aet $=0.85 \times$ MAAP, 505 points, $R^{2}=0.98$, Dall'Osto et al., 2013a).

The TSI ATOFMS collects bipolar mass spectra of individual aerosol particles (Gard et al., 1997). Two ATOFMSs were deployed simultaneously during the SAPUSS field study at the RS (TSI 3800-100, aerodynamic lens) and at the UB (TSI 3800, nozzle/skimmer), respectively. Whilst the efficiency of the former is heavily biased towards the super micron aerosol (Gard et al., 1997), the latter focuses on a narrow particle beam for sizes between $100 \mathrm{~nm}$ and $3 \mu \mathrm{m}(\mathrm{Su}$ 
et al., 2004). Two HR-ToF-AMSs (De Carlo et al., 2006) were deployed during the SAPUSS, co-located next to the two ATOFMS at the super sites RS and UB. It was not possible to intercompare the particle mass spectrometers due to complex logistical issues.

\subsubsection{Off-line chemical analysis techniques}

PM mass concentrations were determined by standard gravimetric procedures as described in Sect. 3.1.3. Filter samples were collected and analysed following the procedures described by Querol et al. (2001b): Al, Ca, K, Mg, Fe, Ti, Mn, P, $\mathrm{S}, \mathrm{Na}$ and 25 trace elements by conventional methods including inductively coupled plasma atomic emission spectrometry and mass spectrometry (ICP-AES and ICP-MS, respectively), $\mathrm{SO}_{4}^{2-}, \mathrm{NO}_{3}^{-}$and $\mathrm{Cl}^{-}$by ion chromatography (IC), and $\mathrm{NH}_{4}^{+}$by selective electrode. A section of $1.5 \mathrm{~cm}^{2}$ of the filter was used for the determination of organic carbon (OC) and elemental carbon (EC) by a thermal-optical transmission technique (Birch and Cary, 1996) using a Sunset Laboratory OCEC Analyzer with the EUSAAR2 temperature programme (Cavalli et al., 2010). Additionally, 1/8 part of the filter was treated for OC speciation (31 organic compounds in total). Further information on the source apportionment of submicron organic aerosol at the SAPUSS UB and RS sites can be found elsewhere in this special issue (Alier et al., 2013).

Hourly elemental concentrations were obtained at the RS and UB by a two-stage $(0.1-2.5 \mu \mathrm{m}$ and $2.5-10 \mu \mathrm{m}$, fine and coarse, respectively) streaker sampler (Formenti et al., 1996). A total of 640 hourly samples were collected and analysed by PIXE at the LABEC-INFN facility in Florence (Chiari et al., 2005). X-ray spectra were analysed for 25 elements $(\mathrm{Na}, \mathrm{Mg}$, $\mathrm{Al}, \mathrm{Si}, \mathrm{P}, \mathrm{S}, \mathrm{Cl}, \mathrm{K}, \mathrm{Ca}, \mathrm{Ti}, \mathrm{V}, \mathrm{Cr}, \mathrm{Mn}, \mathrm{Fe}, \mathrm{Ni}, \mathrm{Cu}, \mathrm{Zn}, \mathrm{As}, \mathrm{Se}$, $\mathrm{Br}, \mathrm{Rb}, \mathrm{Sr}, \mathrm{Zr}$, Mo and $\mathrm{Pb}$ ). The results of the PIXE analysis can be found in this SAPUSS special issue (Dall'Osto et al., 2013b).

\subsubsection{Gaseous pollutants: $\mathrm{O}_{3}, \mathrm{NO}, \mathrm{NO}_{2}, \mathrm{CO}, \mathrm{SO}_{2}, \mathrm{NH}_{3}$}

Standard continuous gas measurements were taken for $\mathrm{SO}_{2}$ (UV fluorescence), $\mathrm{NO}-\mathrm{NO}_{2}-\mathrm{NO}_{\mathrm{x}}$ (chemiluminescence), $\mathrm{CO}$ (IR absorption) and $\mathrm{O}_{3}$ (UV absorption) at four sites (RS, $\mathrm{UB}, \mathrm{TCg}, \mathrm{RB}$ ). Atmospheric $\mathrm{NH}_{3}$ levels were determined by means of ALPHA passive dosimeters (Adapted Low-cost Passive High Absorption sampler; Tang et al., 2001; Reche et al., 2012) at all six monitoring sites. The total number of samples collected was four weekly samples/site at TM, UB, RS and TCg, and two weekly samples/site at RB and TC.

\subsection{Modelling activities}

\subsubsection{Air mass back trajectory analysis}

The study area is affected by convergence of air masses with different characteristics: the cold air coming down from medium and high latitudes, and the warm air coming up from tropical and subtropical latitudes. Back trajectories of the air masses arriving at Barcelona were calculated four times for each day of the campaign (00:00, 06:00, 12:00 and 18:00 UTC), depicting the path taken by the air mass reaching the sampling site over the previous five days. The back trajectories were run using the on-line HYSPLIT model developed by the National Oceanic and Atmospheric Administration (NOAA) (Draxler and Rolph, 2003). Air mass "types" are usually classified according to latitude and their continental or maritime source regions (Bergeron classification). However, during SAPUSS air mass back trajectories, "meteorological regimes" names were also used: Atlantic (ATL), European Mediterranean (EUR), North African (NAF) and regional (REG) meteorological regimes. Such validated methodology is described elsewhere (Rogriguez et al., 2002; Pey et al., 2010). It is also important to note that, in order to interpret the regional and long-range transport of air masses over the study area, complementary tools were also used (Pey et al., 2010).

\subsubsection{Chemical transport models}

The regional modelling system consists of a climatic version of the Fifth-Generation Pennsylvania State UniversityNational Center for Atmospheric Research Mesoscale Model (MM5) (Dudhia, 1993; Grell et al., 1994), coupled off-line to CHIMERE chemistry transport model (Schmidt et al., 2001; Bessagnet et al., 2004). Emissions are taken from the EMEP database (Vestreng et al., 2009) and disaggregated following spatial proxy data, according to the methodology stated in Pay et al. (2010). MELCHIOR2 gas-phase mechanism is implemented within CHIMERE (Derognat et al., 2003). The physico-chemical parameterizations selected for modelling SAPUSS campaign are as follows(Rouil et al., 2009): (1) gas-phase solver - TWOSTEP based on Gauss-Seidel iteration scheme; (2) horizontal and vertical advection schemes - Van Leer (horizontal) and UP-WIND (vertical); (3) vertical diffusion - BLM; (4) deposition - resistance scheme. Aerosol deposition is also based on Wesely modified by Seinfeld and Pandis (2006). Corrections of the vegetal cover have been introduced after. The last is (5) convective mixing (cloud module) - Tiedtke parameterization.

The chemistry transport model includes aerosol and heterogeneous chemistry; distinguishes among different chemical aerosol components, namely nitrate, sulfate, ammonium, elemental and organic carbon with three subcomponents (primary, secondary anthropogenic and secondary biogenic) and marine aerosols. Unspecified primary anthropogenic aerosols and aerosol water are additionally kept as separate components. The model considers the thermodynamic equilibrium using the ISORROPIA model (Nenes et al., 1998). Last, the aerosol microphysical description for CHIMERE is based on a sectional aerosol module including 6 bins from $10 \mathrm{~nm}$ to $40 \mu \mathrm{m}$ using a geometrical progression. 
Table 3. Classification of air mass origins during SAPUSS.

\begin{tabular}{|c|c|c|c|c|c|c|c|}
\hline \multirow[t]{2}{*}{ Calendar day } & \multirow[t]{2}{*}{ Day of week } & \multirow[t]{2}{*}{ Holiday day } & \multicolumn{5}{|c|}{ AIR MASS TYPE } \\
\hline & & & 00:00 UTC & 06:00 UTC & 12:00 UTC & 18:00 UTC & Day air mass \\
\hline $19 / 09 / 2010$ & Sunday & $\mathrm{V}$ & REG & REG & REG & REG & REGIONAL \\
\hline 20/09/2010 & Monday & & REG & REG & REG & REG & REGIONAL \\
\hline $21 / 09 / 2010$ & Tuesday & & REG & REG & REG & REG & REGIONAL \\
\hline $22 / 09 / 2010$ & Wednesday & & AS/NAF & AS/NAF & AS/NAF & AS/NAF & NAF \\
\hline 23/09/2010 & Thursday & & NAF & NAF & NAF & NAF & NAF \\
\hline 24/09/2010 & Friday & $\mathrm{V}$ & REG & REG & REG & REG & Transition \\
\hline 25/09/2010 & Saturday & $\mathrm{V}$ & $\mathrm{AN}$ & $\mathrm{AN}$ & AN & $\mathrm{AN}$ & ATLANTIC \\
\hline 26/09/2010 & Sunday & $\mathrm{V}$ & AN & $\mathrm{AN}$ & $\mathrm{AN}$ & AN & ATLANTIC \\
\hline 27/09/2010 & Monday & & $\mathrm{AN}$ & $\mathrm{AN}$ & $\mathrm{AN}$ & $\mathrm{AN}$ & ATLANTIC \\
\hline 28/09/2010 & Tuesday & & $\mathrm{AN}$ & $\mathrm{AN}$ & $\mathrm{AN}$ & $\mathrm{AN}$ & ATLANTIC \\
\hline 29/09/2010 & Wednesday & & REG & REG & REG & REG & REGIONAL \\
\hline $30 / 09 / 2010$ & Thursday & & REG & REG & REG & REG & REGIONAL \\
\hline 01/10/2010 & Friday & & REG & REG & REG & REG & REGIONAL \\
\hline $02 / 10 / 2010$ & Saturday & V & REG & REG & REG & REG & Transition \\
\hline 03/10/2010 & Sunday & V & R/NAF & R/NAF & R/NAF & R/NAF & NAF \\
\hline 04/10/2010 & Monday & & R/NAF & AN & $\mathrm{AN}$ & AN & Transition \\
\hline 05/10/2010 & Tuesday & & AN & AN & $\mathrm{AN}$ & AN & ATLANTIC \\
\hline 06/10/2010 & Wednesday & & AN & REG & REG & REG & Transition \\
\hline 07/10/2010 & Thursday & & NAF & NAF & NAF & NAF & NAF \\
\hline 08/10/2010 & Friday & & NAF & NAF & NAF & NAF & NAF \\
\hline 09/10/2010 & Saturday & V & NAF & NAF & NAF & NAF & NAF \\
\hline $10 / 10 / 2010$ & Sunday & V & NAF & NAF & MED & MED & Transition \\
\hline $11 / 10 / 2010$ & Monday & V & MED & EUR & EUR & EUR & Transition \\
\hline $12 / 10 / 2010$ & Tuesday & $\mathrm{V}$ & EUR & EUR & EUR & EUR & EUROPE \\
\hline $13 / 10 / 2010$ & Wednesday & & EUR & EUR & REG & REG & Transition \\
\hline $14 / 10 / 2010$ & Thursday & & REG & REG & REG & REG & REGIONAL \\
\hline $15 / 10 / 2010$ & Friday & & REG & REG & REG & REG & REGIONAL \\
\hline $16 / 10 / 2010$ & Saturday & V & REG & REG & REG & REG & REGIONAL \\
\hline $17 / 10 / 2010$ & Sunday & $\mathrm{V}$ & REG & REG & $\mathrm{AN}$ & AN & REGIONAL \\
\hline $18 / 10 / 2010$ & Monday & & AN & AN & $\mathrm{AN}$ & $\mathrm{AN}$ & ATLANTIC \\
\hline $19 / 10 / 2010$ & Tuesday & & AN & AN & $\mathrm{AN}$ & AN & ATLANTIC \\
\hline
\end{tabular}

Further description of the modelling system can be found in Jiménez-Guerrero et al. (2011a, b).

The simulations cover the period of the SAPUSS campaign, with a final horizontal resolution of $0.5 \mathrm{~km}$ for the Barcelona Metropolitan Area; 24 sigma levels are considered in the vertical, with the top at $100 \mathrm{hPa}$. To achieve this high resolution, the spatial model configuration consists of three two-way nested domains with horizontal spatial resolutions of around $10 \mathrm{~km}$ for the Iberian Peninsula, $2 \mathrm{~km}$ for Catalonia and $0.5 \mathrm{~km}$ for the Barcelona Metropolitan Area driven by ERA-Interim reanalysis. Outputs were saved every hour for the entire period of simulation.

Boundary conditions for the external domain (Iberian Peninsula) are based on the global climate chemistry model LMDz-INCA2 $\left(96 \times 72\right.$ grid cells, namely $3.75^{\circ} \times 2.5^{\circ}$ in longitude and latitude, with $19 \sigma$-p hybrid vertical levels, as stated in CHIMERE documentation (e.g. Rouil et al., 2009)). Because the contribution of long-range transport on ground level concentrations (those considered in this work) can be considered as negligible, the influence of using climatological boundary conditions is limited and overwhelmed by local processes. However, in order to prevent the influence of boundary conditions, a blending area of five grid points is excluded from the analysis hereafter.

For the sake of brevity, and because the objective is to contribute with the highest possible resolution to the SAPUSS campaign, just results for the inner domain are shown in this contribution.

\section{Results}

\subsection{Air mass back trajectory analysis}

Five air mass meteorological regimes were classified during the SAPUSS field study (Fig. 3). Table 3 shows that 23 days during SAPUSS presented the same air mass type within $24 \mathrm{~h}$ of each day, whereas days with multiple air mass types within the same day were classified as "transition" (Table 3, Fig. 3). 




Fig. 3. Atmospheric pressure $(\mathrm{mb})$ and temporal trend of air mass origins during SAPUSS.

It is important to clarify that the classification was made not only according to air mass back trajectories, but also by looking at the local meteorological data available at the five sampling sites. Further information on the local meteorology associated with the air mass types described in Sects. 4.1.14.1.5 below can also be found in Sect. 4.2.

\subsubsection{Regional air mass (REG)}

A typical REG meteorological regime is shown in Fig. 3. This air mass type (continental polar) was found the one occurring most frequently during the SAPUSS field study, for a total of 9 days. Three distinct episodes were found: 20 21 September, 29 September-1 October and 14-17 October. Regional air masses are typical during the summer months in the western Mediterranean, with higher temperatures and greater insolation (Millan et al., 1997). The Azores anticyclones dominate the pressure system and, at the same time, large thermal low systems develop over the Iberian Peninsula with land-sea breezes being very active over the coasts (Millan et al., 2000). These regional episodes are developed under meteorological regimes characterized by a lack of a significant synoptic air mass advection. Whilst the schematic of the complex development of mesoscale atmospheric recirculation has already been presented in great detail (Millan et al., 2000), a conceptual figure with the SAPUSS monitoring sites is presented in Fig. 1c. Finally, Fig. 4 shows average temperature but lower WS for this air mass type (relative to the others).

\subsubsection{Atlantic air mass (ATL)}

ATL meteorological regime (marine polar air type) was the second most frequent one during the SAPUSS project, characterizing a total of 7 sampling days. Three distinct episodes were found: 25-28 September, 5 October and 18-19 October. ATL meteorological regimes possess intensive advections from the Atlantic Ocean, associated with cold fronts crossing the IP. Meteorological values for this air mass type showed the driest conditions recorded during the study (Fig. 4a) associated with the coldest temperatures (Fig. 4b), sunny days (Fig. 4c) and strong northerly winds (Figs. 4d, 5).

\subsubsection{European air mass (EUR)}

This meteorological regime originated on the east side of the European continent (continental polar air mass type) and crossed all of Europe before arriving in Spain. Such conditions began at 08:00 UTC on 11 October lasting continuously for more than two days till 15:00 UTC on 13 October (Fig. 3). The transport of particulate pollutants from mainland Europe has already been reported as potential meteorological regime for high PM episodes, although wet/rainy weather situations and strong winds favouring pollutant dilution and scavenging may also show an opposite trend (Rogriguez et al., 2002). 


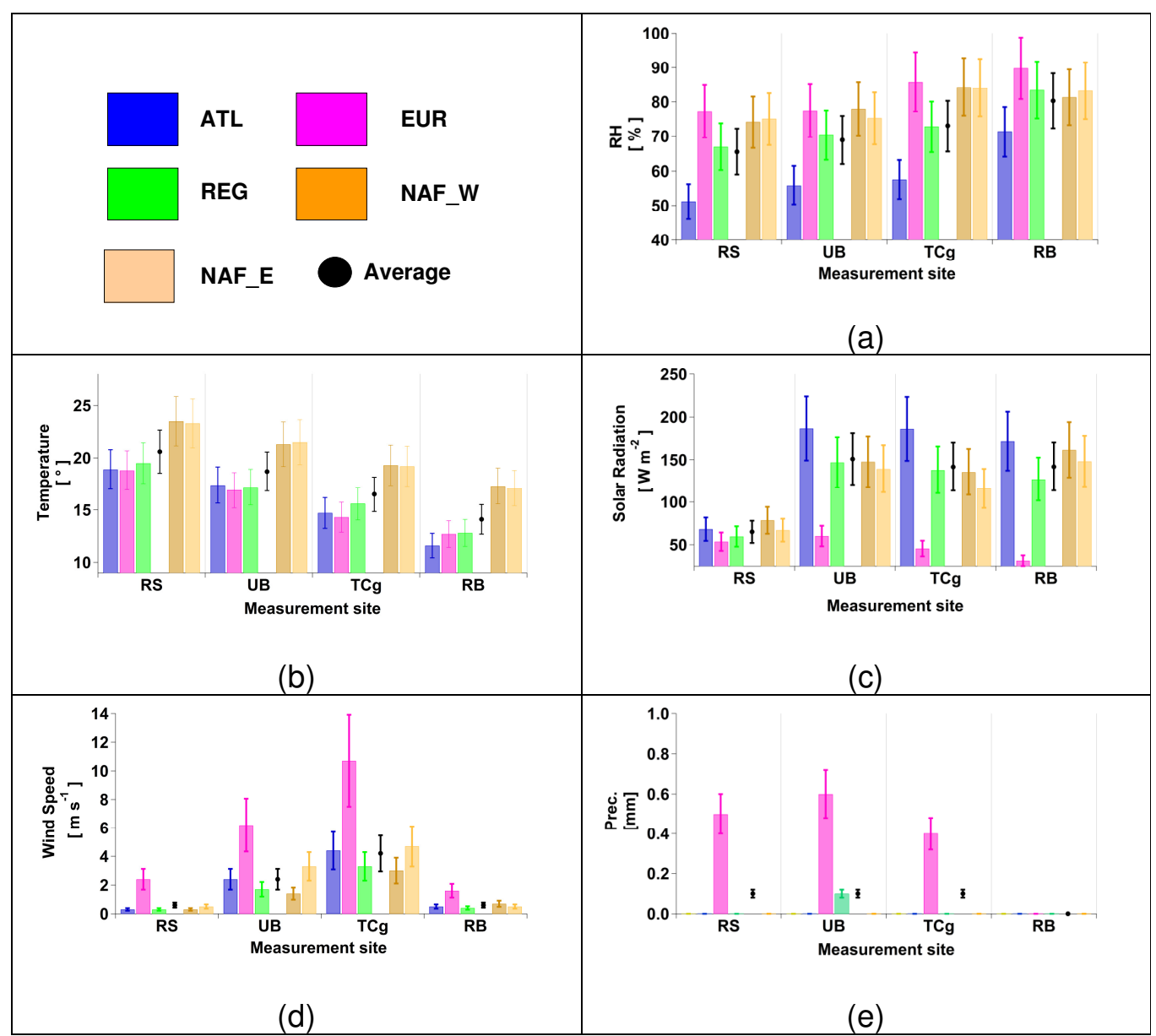

Fig. 4. Average (a) RH, (b) temperature, (c) solar radiation, (d) wind speed and (e) rain precipitation during SAPUSS for different air mass types at four different monitoring sites. Please note black dots show average values during SAPUSS $( \pm 1 \sigma)$.

Figure 4a shows that the EUR meteorological regime is characterized by the lowest solar radiations (Fig. 4c), strongest wind (Fig. 4d) and the wettest conditions of the entire SAPUSS field study (Fig. 4e), from easterly directions (Fig. 5).

\subsubsection{East and west North African air mass (NAF_E and NAF_W)}

Three events (six days in total) were found for this continental/marine tropical air mass type (Fig. 3). Those air masses were found to be the warmest ones encountered during the SAPUSS campaign (Fig. 4b), about $4{ }^{\circ} \mathrm{C}$ warmer than any other air mass type. According to Escudero et al. (2005), four meteorological meteorological regimes originate in the transport of African air masses towards the WMB: (1) a North African high located at surface levels (NAH-S), (2) an Atlantic depression (AD) situated in front of Portugal, (3) a North African depression (NAD), and (4) a North African high located at upper levels (NAH-A). During the SAPUSS, two different NAF meteorological regimes were classified and named as NAF_E and NAF_W, respectively. Figure 3 shows an air mass trajectory that originated in the tropical Atlantic Ocean and arriving from the south-west direction to Barcelona (NAF_W) (Figs. 3 and 5). By contrast, the NAF_E air mass type originated in the Saharan region and arrived at Barcelona from the easterly wind sector, as clearly seen in the associated wind roses (Fig. 5).

\subsection{Local meteorology}

Meteorological conditions during SAPUSS appear in Fig. 4. Average temperatures at the urban ground sites (RS $20.6^{\circ}$ and UB $18.7^{\circ}$ ) were found higher than the other sites, due to the urban heat island of Barcelona, whereas colder temperatures were found both at higher elevations and remote regional sites ( $\mathrm{TCg} 16.5^{\circ}$ and $\left.\mathrm{RB} 14.1^{\circ}\right)$. Figure 6 shows the diurnal profiles of $T$ (Fig. 6a), RH (Fig. 6b), solar radiation (Fig. 6c) and WS (Fig. 6d) for the whole SAPUSS sampling period. Typical diurnal profiles can be seen for RH and $T$ at all sites, with the ground urban ones (RS and UB) presenting 




Fig. 5. Wind roses at four different SAPUSS monitoring sites for all study (ALL) and for selected air mass types.

the strongest day/night variation. For all the monitoring sites, the warmest part of the day was found at 15:00 UTC in the afternoon. The solar radiation cycle started at about 07:00 UTC and terminated at about 20:00 UTC (Fig. 6). During the SAPUSS, the sun rose at 07:36-08:08 UTC, and the sun set at 19:06-19:54 UTC (local time, UTC+2). Figure 6 shows that not only TM but also the RS site is affected by the shadows of nearby buildings.

As regard of WS, Fig. 6d showed the strongest wind speed at TCg $\left(4.2 \mathrm{~m} \mathrm{~s}^{-1}\right)$, followed by the UB site $\left(2.4 \mathrm{~m} \mathrm{~s}^{-1}\right)$. Whilst the RS site presented generally low WS (lacking of a clear diurnal trend due to its street canyon characteristic), the UB and RB show typical diurnal variations associated with the sea breeze circulation patterns. However, opposite trends are seen for the $\mathrm{TCg}$. The sea breezes (usually originating from about $60^{\circ}$ and moving towards the dominant $120-180^{\circ}$ sector) are at their strongest around midday, when the boundary layer height maximizes (Perez et al., 2004).

When looking at the wind roses presented in Fig. 5, different wind pattern regimes were found under different air mass meteorological regimes. Northerly winds were recorded at the UB and TC sites. By contrast, giving the fact that the WS at the RB and RS were often below $2 \mathrm{~m} \mathrm{~s}^{-1}$, WD data for these sites are indeed more variable and do not really allow any firm conclusion to be drawn. Finally, Fig. 7 summarizes the WS and the WD diurnal patterns for representative days of the five meteorological regimes described in Sect. 4.1:

- ATL (25 September 2010, Fig. 7a): Atlantic air masses are characterized by strong winds from the north-east-north-west sector for the RS and UB urban sites. Whilst uncommon during wintertime, during 




Fig. 6. Diurnal average temperature (a), RH (b), solar radiation (c) and wind speed (d) at five different SAPUSS monitoring sites.

summertime the sea breeze circulation can occur, as seen at the RB site.

- EUR (12 October 2010, Fig. 7b): this is a very peculiar air mass type, with strong wind coming mainly from the east sector. The absence of sea breeze circulation is also a key feature of this air mass type.

- REG (30 September 2010, Fig> 7c): a typical sea breeze pattern is seen at all sites, although not at the TCg site.

- NAF_W (3 October 2010, Fig. 7d): strong southwest direction remarkably constant during all day for all sites. The sea breeze circulation blowing from the same westerly direction enhances the WS during the warmest part of the day.

- NAF_E (9 October 2010, Fig. 7e): a remarkable easterly WD is observed during all day at both TC and UB sites. The RB site also shows an easterly WD during the warmest part of the day when the see breeze blows wind into the Besòs Valley (see map in Fig. 1a).

\subsection{Level of gaseous pollutants}

Table 4 reports the average concentrations for all gases at the five different monitoring sites. Please note that the only gaseous measurement taken at the TM site was for $\mathrm{NH}_{3}$, whereas the other four monitoring sites present a wider data coverage.

\subsection{1 $\quad \mathrm{NH}_{3}$}

Table 4 shows remarkably higher mean $\mathrm{NH}_{3}$ levels at the urban sites (RS, UB and TM, 2.0-3.1 $\mu \mathrm{g} \mathrm{m}^{-3}$ ), when compared to the ones detected at the background sites TC and TCg. $\left(1.0-1.1 \mu \mathrm{g} \mathrm{m}^{-3}\right)$ and at the regional background (RB, $\left.0.5 \mu \mathrm{g} \mathrm{m}^{-3}\right)$. A certain gradient is even evident among the urban sites, increasing from 2.0 to $3.1 \mu \mathrm{g} \mathrm{m}^{-3}$ from the UB to the traffic environment (RS). This points to vehicular traffic as a main source influencing the spatial variability of atmospheric ammonia among the study sites. It is also interesting to note that the $\mathrm{NH}_{3}$ levels registered at the $\mathrm{TC}$ and $\mathrm{TCg}$ sites are within one standard deviation of each other, as it would be expected given that these sites are located in close proximity to each other. Mean $\mathrm{NH}_{3}$ levels at $\mathrm{TM}$ and UB sites are also similar, despite the markedly different environments. The TM site is located above the ground but in proximity of a busy motorway, whereas the UB site is located at ground level but in the background urban area. Overall, ammonia concentrations detected in Barcelona during SAPUSS were of the same order of magnitude as those detected in Houston, USA (2.1 $\mu \mathrm{g} \mathrm{m}^{-3}$, Gong et al., 2011), but much lower 




Fig. 7. Diurnal WS and WD average measurements at four SAPUSS monitoring sites under different air mass types.

than the ones detected in Beijing, China $\left(14 \mu \mathrm{g} \mathrm{m}^{-3}\right.$, Meng et al., 2011). It is important to note that traffic, as well as the city waste collection system, is a major source of $\mathrm{NH}_{3}$ in the city of Barcelona, with overall average concentrations of $9.5 \mathrm{mg} \mathrm{m}^{-3}$ and $4.4 \mathrm{mg} \mathrm{m}^{-3}$ during summer and winter, respectively (Reche et al., 2012).

\subsubsection{Other gaseous pollutants}

The analysis and the trends observed for different gaseous pollutants in Barcelona - and its comparison with other European cities - can be found in Reche et al. (2011). Briefly, higher ozone concentrations (due to intense photochemical activity, Millan et al., 2000) and higher $\mathrm{NO}_{\mathrm{x}}$ (due to the high vehicle density and the high percentage of diesel vehicles) are often seen in urban background locations in Barcelona (and southern Europe) relative to other northern and central European cities (Eeftens et al., 2012).

During SAPUSS, traffic markers such as $\mathrm{NO}$ and $\mathrm{CO}$ showed as expected the highest values at the RS site $\left(8.8 \pm 12 \mu \mathrm{g} \mathrm{m}^{-3}\right.$ and $0.4 \pm 0.3 \mu \mathrm{g} \mathrm{m}^{-3}$, respectively, Table 4) and the lowest values towards the RB site following the order RS, UB, TCg and RB, and representative of the distance from hotspot traffic sources.

Although low in absolute value, $\mathrm{SO}_{2}$ levels were also found to be the highest at the RS traffic site $\left(2.1 \mu \mathrm{g} \mathrm{m}^{-3}\right)$, as a direct effect of exhaust emissions. Lower $\mathrm{SO}_{2}$ values were generally found in Barcelona when compared to other $\mathrm{Eu}-$ ropean cities (Reche et al., 2011). During some stagnant air mass conditions (29 September-1 October), higher levels of $\mathrm{SO}_{2}$ were found at the TCg site (situated in a hill near the city of Barcelona, Fig. 1) relative to the ground site (RS and UB), 
Table 4. Average gaseous concentrations at different sites during SAPUSS (NA: not available). * Average between TC (1.0 \pm 0.4$)$ and TCg $(1.1 \pm 0.4)$.

\begin{tabular}{llrrrrr}
\hline & \multicolumn{5}{c}{ Measurement sites } \\
\cline { 3 - 7 } & & $\mathrm{RS}$ & $\mathrm{UB}$ & $\mathrm{TCg}$ & $\mathrm{TM}$ & $\mathrm{RB}$ \\
\hline Gaseous poll. & $\mathrm{NO}$ & $8.8 \pm 12$ & $5.2 \pm 13$ & $1.5 \pm 1.6$ & $\mathrm{NA}$ & $1.0 \pm 0.2$ \\
{$\left[\mu \mathrm{g} \mathrm{m}^{-3}\right]$} & $\mathrm{NO}_{2}$ & $37 \pm 19$ & $28 \pm 21$ & $15 \pm 12$ & $\mathrm{NA}$ & $3.8 \pm 3.9$ \\
& $\mathrm{NO}_{\mathrm{x}}$ & $46 \pm 20$ & $33 \pm 25$ & $17 \pm 13$ & $\mathrm{NA}$ & $5 \pm 4$ \\
& $\mathrm{CO}$ & $0.4 \pm 0.3$ & $0.3 \pm 0.2$ & $0.3 \pm 0.1$ & $\mathrm{NA}$ & $0.2 \pm 0.3$ \\
& $\mathrm{SO}_{2}$ & $2.1 \pm 2.3$ & $0.3 \pm 1.2$ & $0.7 \pm 2.4$ & $\mathrm{NA}$ & $0.5 \pm 0.6$ \\
& $\mathrm{O}_{3}$ & $43 \pm 21$ & $58 \pm 22$ & $73 \pm 16$ & $\mathrm{NA}$ & $62 \pm 19$ \\
& $\mathrm{NH}_{3}$ & $3.1 \pm 0.4$ & $2.1 \pm 0.5$ & $1.0^{*} \pm 0.4$ & $2.0 \pm 0.6$ & $0.5 \pm 0.2$ \\
\hline
\end{tabular}



Fig. 8. Diurnal variation of gaseous measurements at five different monitoring sites: (a) $\mathrm{NO},(\mathbf{b}) \mathrm{NO}_{2},(\mathbf{c}) \mathrm{NO}_{\mathrm{x}}$, (d) $\mathrm{CO}_{\text {, (e) }} \mathrm{SO}_{2}$. Ozone is reported in Fig. 12a.

pointing towards a stratification of $\mathrm{SO}_{2}$ over the Barcelona urban areas.

Ozone presented also as expected the lowest values at the $\operatorname{RS}\left(43 \pm 21 \mu \mathrm{g} \mathrm{m}^{-3}\right)$ and the UB $\left(58 \pm 22 \mu \mathrm{g} \mathrm{m}^{-3}\right)$ as a consequence of a major consumption of $\mathrm{O}_{3}$ by NO. However, higher values of ozone were found at the $\mathrm{TCg}$ relative to the $\mathrm{RB}$ despite the higher levels of $\mathrm{NO}_{\mathrm{x}}$ at the former site (Table 4). More considerations on ozone concentrations during the SAPUSS are given in Sect. 4.3.3.

Figure 8 shows the hourly diurnal temporal trends calculated for the five gas pollutants monitored simultaneously at the four different sites:
- NO concentrations at the city ground sites of UB and RS show a trend linked with the traffic activity. At the $\mathrm{UB}$, a strong maximum is seen at 08:00 UTC partly due to the strong influence of busy Avenida Diagonal. By contrast, the RS shows a spike at 09:00 UTC which decreases only moderately at about 13:00 UTC, until it increases again during the evening traffic rush hour at around 17:00-22:00 UTC. NO diurnal temporal trends for the $\mathrm{TCg}$ site are shifted (relative to the UB and RS sites) as the maximum concentrations are detected only when the boundary layer is fully developed between 10:00 UTC and 14:00 UTC, allowing the city pollutants to be transported to the background $\mathrm{TCg}$ 




Fig. 9. Diurnal variation at four different monitoring sites for (a) $\mathrm{NO}$, (b) $\mathrm{NO}_{2}$, (c) $\mathrm{SO}_{2}$, (d) $\mathrm{CO}$, (e) $\mathrm{O}_{3}$ for different air mass types. Please note all concentrations are in $\mu \mathrm{g} \mathrm{m}^{-3}$.

site. For the same reasons, the regional background site (RB) shows a peak at about 13:00 UTC, lasting for about $4 \mathrm{~h}$ till about 17:00 UTC (Fig. 8).

- CO concentrations show a similar trend of NO at all sites, confirming its main traffic origin. However, a spike at about 13:00 UTC is seen at the RS, and it is associated with unknown non-traffic combustion sources (Dall'Osto et al., 2013b). At the RB site, CO presented a similar trend like the one seen for $\mathrm{NO}$, whereas a second spike was seen for the more urban background TCg site at about 18:00-20:00 (Fig. 8).

- $\mathrm{NO}_{2}$ concentrations presented a different daily pattern relative to NO, with a second spike during 19:0021:00 UTC for both the RS and the UB. The fact that $\mathrm{NO}$ does not follow completely the $\mathrm{NO}_{2}$ trend especially at night is due to the absence of photolysis of $\mathrm{NO}_{2}$ into $\mathrm{NO}$ in the dark. At the TCg, the morning spike is shifted towards the 11:00 UTC-13:00 UTC window, when the boundary layer is fully developed. By contrast, the evening spike at 17:00-20:00 UTC is decreased in intensity due to lower boundary layer height conditions (Fig. 8).

- $\mathrm{SO}_{2}$ diurnal trends were not well defined during the SAPUSS project, with noisy diurnal trends. Whilst the RS seems to reflect the traffic conditions, at the UB site the $\mathrm{SO}_{2}$ concentration peaks in the afternoon, likely associated with the transport of it from the city by the sea breeze circulation (Reche et al., 2011). By contrast, at the $\mathrm{TCg}$ site the highest $\mathrm{SO}_{2}$ concentrations were found during night-time (Fig. 8).

- Ozone values were found to be linked with $\mathrm{NO}_{\mathrm{x}}$ levels at both UB and RS. High values of $\mathrm{O}_{3}$ were found 




Fig. 10. (a) Diurnal variation of ozone concentrations at 4 SAPUSS monitoring sites (RS, UB, TC, RB) and at REGIONAL Catalonia (average of 7 monitoring stations at regional sites in the province of Catalonia); (b) oxidant plot of the variation in volume mixing ratio of $\mathrm{Ox}\left(\mathrm{NO}_{2}+\mathrm{O}_{3}\right)$ as a function of $\mathrm{NO}_{\mathrm{x}}\left(\mathrm{NO}+\mathrm{NO}_{2}\right)$ for 4 SAPUSS sites. Data are for day (08:00-16:00) and night (20:0008:00) hourly averages for the whole SAPUSS campaign period; (c) variation in the intercept and gradient of the regression analyses of oxidant plots (as shown in Fig. 12b), for each hour of the $24 \mathrm{~h}$ period averaged over the campaign duration.

at the TCg for most of the night-time periods (see Sect. 4.3.3).

When levels of gaseous pollutants from different meteorological regimes are compared, the sea breeze circulation was found to be a key parameter governing their concentration levels. A sea breeze circulation in the topographic and regional context of the WMB may exacerbate air pollution levels by constricting local ventilation and instead recirculating air around multilayered pollution closed cells (Millan et al., 1997). On the other hand, a sea breeze circulation may move relatively clean air onshore that will rapidly lower gas concentrations. Figure 9 shows the diurnal temporal trends for selected gas phase pollutants at the four different monitoring sites according to different meteorological regimes. During morning hours, when the air is still, pollutants can accumulate over their sources or downwind of them. Later in the day, when a local sea breeze circulation develops, a fresh breeze blows in the direction from the sea $\left(120-180^{\circ}\right)$ toward land. In addition to this effect, which generally occurs close to land, the sea breeze circulation itself can penetrate as far inland throughout the two valleys (Llobregat and Besòs, Fig. 1), reaching the RB site.

REG and NAF_W air masses were found to present the highest levels of $\mathrm{NO}$ and $\mathrm{NO}_{2}$ at the UB and RS sites (Fig. 9). During NAF_W air masses pollutants are transported at high concentrations from the city towards the TC and RB sites due to the favourable wind patterns: strong westerly wind blowing parallel to the Besòs Valley (Fig. 1). By contrast, ozone presented a similar trend at the RS and UB for mostly air masses, mainly peaking in the afternoon. However, unusual conditions were found for the European meteorological regime (Fig. 9), with less diurnal variation due to the contribution of regional transport and reduced local traffic sources during raining conditions. After sunrise, the height of the unstable boundary layer begins to increase as the surface is heated and the nocturnal inversion is destroyed, resulting in downward mixing $\mathrm{O}_{3}$ from above (Pandolfi et al., 2013). This may be the reason why there is an increase of ozone in the morning at some of the sampling sites under this EUR air mass scenario (Fig. 9, De Foy et al., 2006).

\subsection{3 $\mathrm{O}_{3} / \mathrm{NO}_{\mathrm{x}}$ chemistry and oxidant plot}

The classic concept of upwind (background concentrations) and downwind of conurbations (polluted) is inappropriate in regions of complex coastal terrain like the WMB, where recirculation processes are important. Indeed, a number of studies have shown that layering and accumulation of pollutants such as tropospheric ozone (Seinfeld and Pandis, 1998; Tong et al., 2011) and aerosols can take place along the WMB coast (Millán et al., 1997, 2000; Jorba et al., 2004). Díaz-de-Quijano et al. (2009) also suggested that the ozone in the Catalan Pyrenees mainly originated from urban areas, which is then transported to high-mountain sites, remaining aloft in absence of NO. Furthermore, a number of multiscale modelling simulation results over Barcelona and other central Mediterranean regions additionally show that the strength of the land-sea breeze circulation and thermally or mechanically driven convection over the complex orography of the eastern Iberian coast can induce vertical transport and the layering of air pollution (Millan et al., 1997; Toll and Baldassano, 2001; Jimenez et al., 2006).

During the SAPUSS field study, the average ozone concentration for the Gencat "regional" air pollution monitoring stations from Catalonia (7 stations: Bellver de Cerdanya, Berga, Ponts, Sant Celoni, Santa Maria de Palautordera, Santa Pau, and Sort) was found to be $55 \pm 10 \mu \mathrm{g} \mathrm{m}^{-3}$ (max. 
value $114 \mu \mathrm{g} \mathrm{m}^{-3}$ ); its average diurnal profile is presented in Fig. 10a. A typical diurnal profile with afternoon maxima typical of regional background environment - can be seen. By contrast, the ozone diurnal variation at the urban ground level (UB, RS) shows a typical urban pattern: minimum levels during morning traffic rush hour and maximum in the afternoon (Fig. 10a). The remaining two SAPUSS background sites (TCg and RB) show high average concentrations during night-time, indicating a residual layer of ozone maintaining at higher elevation in the Besòs Valley (Fig. 10a). The reason is likely due to the fact that turbulence is strongly suppressed in the nocturnal boundary layer. Hence, emissions at the ground are only slowly transported vertically, making nocturnal chemistry dependent on elevation and vertical stability (Wong and Stutz, 2010). By contrast, during the afternoon - when the boundary layer is fully developed (Pandolfi et al., 2013) - the levels of ozone at UB, RB and TC are similar at about $80 \mu \mathrm{g} \mathrm{m}^{-3}$ (Fig. 10a).

Figure 10b shows an "oxidant plot", where the level of total oxidant $\left(\mathrm{OX}=\mathrm{O}_{3}+\mathrm{NO}_{2}\right)$ is plotted as a function of $\mathrm{NO}_{\mathrm{x}}\left(\mathrm{NO}+\mathrm{NO}_{2}\right)$. Oxidant plots such as these have been interpreted as showing both the regional background oxidant (ozone) level, indicated by the $y$ axis intercept, and the local primary contribution to oxidant (potentially primary $\mathrm{NO}_{2}$ emissions), indicated by the gradient (Clapp and Jenkin, 2001).

It is important to remember that ozone values in Table 4, Figs. 9 and 10a are in $\mu \mathrm{g} \mathrm{m}^{-3}$, whereas Fig. 10b shows data in ppb $\left(1 \mathrm{ppb}=2.00 \mu \mathrm{g} \mathrm{m}^{-3}\right)$ in order to stoichiometrically compare $\mathrm{OX}$ and $\mathrm{NO}_{\mathrm{x}}$. The linear regressions obtained in the oxidant plot (Fig. 10b) show a regional daytime contribution for the three urban sites (UB, RS and TCg) remarkably similar at $41-45 \mathrm{ppb}\left(82-90 \mu \mathrm{g} \mathrm{m}^{-3}\right)$. The lower average values of $30 \mathrm{ppb}\left(60 \mu \mathrm{g} \mathrm{m}^{-3}\right)$ for the regional contribution of the RB site may be due to enhanced regional deposition at the RB site and/or the urban heat island effect affecting the ozone concentrations at urban ground level (UB/RS/TCg sites).

The daytime gradients of the $\mathrm{OX}-\mathrm{NO}_{\mathrm{x}}$ relationship shown in Fig. $10 \mathrm{~b}$ are very different and increasing following the order RS (0.05), UB (0.13), TCg (0.34) and RB (1.5). Such a trend reflects the increasing distance from the road (RS), towards the urban background (UB, $\mathrm{TCg}$ ), finally reaching the regional background (RB). As mentioned above, the gradient is thought to be indicative of local primary $\mathrm{NO}_{2}$ emissions, or formation (with $\mathrm{NO}_{\mathrm{x}}$ ) of species which promote $\mathrm{NO}$-to- $\mathrm{NO}_{2}$ conversion (i.e. $\mathrm{RO}_{2}$ radical precursors).

The variation in incoming ozone over the diurnal period (indicated by the intercept, Fig. 10c) shows a clear late morning/early afternoon maximum, peaking at 15:00 UTC, reflecting (modest) regional photochemical ozone production, common to all sites. More complex is the gradient, yet not fully understood. An increase in the gradient in the evening shows a stable night-time atmosphere trapping $\mathrm{NO}_{\mathrm{x}}$, whereas a decline in the evening may reflect nitric acid formation via $\mathrm{N}_{2} \mathrm{O}_{5}$ and loss of $\mathrm{NO}_{\mathrm{x}}$ by deposition or aerosol formation.
$\mathrm{NO}$ effectively curtails the night-time $\mathrm{NO}_{3}-\mathrm{N}_{2} \mathrm{O}_{5}$ chemistry, although Benton et al. (2010) found that the $\mathrm{N}_{2} \mathrm{O}_{5}$ formation above an urban city is significant. Despite its importance, many aspects of tropospheric $\mathrm{N}_{2} \mathrm{O}_{5}$ chemistry are still not well known (Brown et al., 2006; Chang et al., 2011). There is a clear lack of observations of $\mathrm{NO}_{3}$ chemistry on polluted atmospheres, and the strong impact of vertical stability of the boundary layer makes nocturnal chemistry highly elevation dependent (Stutz et al., 2009; Harrison et al., 2012).

\subsection{Aerosol particle number and mass concentrations}

\subsubsection{Aerosol particle number concentrations $(N)$}

The highest concentration of averaged particle number concentrations was found at the RS $\left(N_{>7}: 12890 \pm 6300 \mathrm{~cm}^{-3}\right)$, followed by UB $\left(N_{>5}: 10490 \pm 5900 \mathrm{~cm}^{-3}\right)$, TM $\left(N_{>7}\right.$ : $\left.9590 \pm 6400 \mathrm{~cm}^{-3}\right)$, TC $\left(N_{>7}: 5500 \pm 3800 \mathrm{~cm}^{-3}\right)$ and RB $\left(N_{>5}: 2600 \pm 1800 \mathrm{~cm}^{-3}\right)$ sites. This is consistent with road traffic being a major source of $N$. Many studies have focused on the evolution of vehicular particles during advection away from the source, with very few studies focused on the vertical variations of particle number concentrations and size distributions. Whilst a more in depth analysis can be found in other manuscripts of this special issue (Dall'Osto et al., 2012, 2013a), it is worth reporting that during SAPUSS particle number concentrations $(N>5 \mathrm{~nm})$ were highly correlated with black carbon (BC) at all sites only under strong vehicular traffic influences. By contrast, under cleaner atmospheric conditions (low condensation sink, CS) such correlation diverges towards much higher $N / \mathrm{BC}$ ratios at all sites, indicating additional sources of particles including secondary production of freshly nucleated particles. In other words, the SAPUSS study suggests that the column of air above the city ground level possesses the optimal combination between low CS and high vapour source, hence enhancing the concentrations of freshly nucleated particles (Dall'Osto et al., 2013a).

During SAPUSS not only $N$ was measured, but also sizeresolved aerosol particle number concentrations were taken. Aerosol number size distributions in the urban area are mainly a function of a number of factors, including primary emissions (i.e. traffic, power plants, cooking and heating), meteorological factors, and long-range transport of different sources of diverse regions (Hussain et al., 2006). Future extensive analysis of aerosol size distributions obtained during SAPUSS will be carried out by using a novel application of cluster analysis (Beddows et al., 2009) and positive matrix factorization (Harrison et al., 2011).

\subsubsection{Aerosol mass loadings averages}

During the 32 days of the SAPUSS field study, the $\mathrm{PM}_{10}$ daily limit $\left(50 \mu \mathrm{g} \mathrm{m}^{-3}\right.$, EEA, 2010) was never exceeded in any of the monitoring sites. Table 5 shows the average $\mathrm{PM}_{10}, \mathrm{PM}_{2.5}$ and $\mathrm{PM}_{1}$ concentrations measured both 
Table 5. Average aerosol mass loadings during SAPUSS.

\begin{tabular}{|c|c|c|c|c|c|c|}
\hline Monitoring site & $\mathrm{PM}_{10}$ & $\mathrm{PM}_{2.5}$ & $\mathrm{PM}_{1}$ & $\mathrm{PM}_{2.5} / \mathrm{PM}_{10}$ & $\mathrm{PM}_{1} / \mathrm{PM}_{10}$ & Availability (\%) \\
\hline \multicolumn{7}{|c|}{ Grimm } \\
\hline RS & 30.7 & 18.6 & 16.3 & 0.61 & 0.53 & 100 \\
\hline UB & 25.9 & 16.2 & 12.4 & 0.63 & 0.48 & 98 \\
\hline TM & 24.8 & 17.7 & 14.7 & 0.71 & 0.59 & 88 \\
\hline $\mathrm{TC}$ & 19.2 & 16.9 & 14.0 & 0.88 & 0.73 & 45 \\
\hline $\mathrm{TCg}$ & 21.8 & 15.8 & 11.1 & 0.73 & 0.51 & 70 \\
\hline $\mathrm{RB}$ & 20.0 & 10.9 & 10.4 & 0.54 & 0.52 & 100 \\
\hline \multicolumn{7}{|c|}{ Gravimetric } \\
\hline $\mathrm{RS}$ & 31.2 & 17.9 & 16.4 & 0.57 & 0.52 & $\left(\mathrm{PM}_{10}-\mathrm{PM}_{2.5}-\mathrm{PM}_{1}\right) 92 / 92 / 92$ \\
\hline UB & 25.8 & 16.2 & 12.3 & 0.63 & 0.48 & $85 / 78 / 78$ \\
\hline TM & 24.1 & - & - & - & - & $92 /-1-$ \\
\hline $\mathrm{TC}$ & - & - & - & - & - & - \\
\hline $\mathrm{TCg}$ & 19.2 & - & - & - & - & $90 /-/-$ \\
\hline $\mathrm{RB}$ & 22.3 & 10.9 & 9.9 & 0.49 & 0.45 & $48 / 67 / 42$ \\
\hline
\end{tabular}

gravimetrically and by optical counters. Similar size fraction variations and inter-sites variations were observed for both the gravimetric and the optical data. For coherence and higher data coverage, only gravimetrically corrected optical data are herein discussed. The highest $\mathrm{PM}_{10}$ concentrations were recorded at the RS site $\left(31 \mu \mathrm{g} \mathrm{m}^{-3}\right)$, followed by the UB $\left(26 \mu \mathrm{g} \mathrm{m}^{-3}\right)$ and the TM $\left(25 \mu \mathrm{g} \mathrm{m}^{-3}\right)$ urban sites. The lowest $\mathrm{PM}_{10}$ concentrations were recorded at background $\mathrm{TC}, \mathrm{TCg}$ and RB sites, suggesting that the city surface is enhanced in coarse particles (Amato et al., 2009). By contrast, whilst the $\mathrm{PM}_{1}$ showed the highest concentration also at the RS site $\left(16 \mu \mathrm{g} \mathrm{m}^{-3}\right)$, the second highest concentrations were found at the tower sites (TM, TC) followed by the ground sites (TCg, UB, RB). This is better seen in the $\mathrm{PM}_{1} / \mathrm{PM}_{10}$ ratios, showing the highest values of 0.6 and 0.7 at the TM and TC, respectively. These results are in line with a recent study conducted in London, showing higher concentrations of fine aerosol above the city, where the cooler temperatures and higher relative humidity may shift the gas/aerosol ammonium nitrate equilibrium towards the aerosol phase (Harrison et al., 2012). It is important to note that the high $\mathrm{PM}_{1} / \mathrm{PM}_{10}$ ratios at the towers (TM, TC) are not only due to the low $\mathrm{PM}_{10}$ concentrations, as the absolute values of $\mathrm{PM}_{1}$ detected at the tower sites were also higher than the urban background ground levels (UB, TCg, Table 5). $\mathrm{PM}_{2.5}$ did not show any clear trend at the urban sites, with average values of $17 \pm 2 \mu \mathrm{g} \mathrm{m}^{-3}$; whereas at the RB site the $\mathrm{PM}_{2.5}$ concentrations were significantly lower $\left(10.9 \mu \mathrm{g} \mathrm{m}^{-3}\right)$. When comparing PM concentrations within each monitoring site (Table 6), expected high correlations were found between $\mathrm{PM}_{1}$ and $\mathrm{PM}_{2.5}\left(R^{2} 0.8-0.95\right)$ and between $\mathrm{PM}_{2.5}$ and $\mathrm{PM}_{10}\left(R^{2}\right.$ 0.7-0.9); whereas weaker ones between $\mathrm{PM}_{1}$ and $\mathrm{PM}_{10}\left(R^{2}\right.$ $0.5-0.6)$. When analysing the inter-site variability - excluding the RB site $-\mathrm{PM}_{1}$ and $\mathrm{PM}_{2.5}$ were found to be moder- ately correlated $\left(R^{2} 0.6\right.$ and 0.55 , averaged by considering all sites, respectively) suggesting a weak regional distribution of the aerosols in the fine ranges. By contrast, $\mathrm{PM}_{10}$ presented lower average $R^{2}(0.3)$, suggesting a higher dependence on local sources. The two tower sites (urban tower TM, suburban tower TC) did not show a strong correlation, indicating differences in the column of air above the urban agglomerate. Furthermore, this is also expected since the TC tower site is located inland whereas the TM tower site at the seashore. Overall, the total average $R^{2}$ values (average of $R^{2}$ of each size fraction with the same size fraction at the rest of the sites) were, in order, 0.23 (RB), 0.33 (RS), 0.43 (TC), 0.47 (TM), 0.52 (UB) and 0.62 (TCg). This indicates that the RB site was - as expected - disconnected from the urban monitoring sites. The RS was strongly affected by the traffic local source, hence also presenting low correlations with the rest of the monitoring sites. This was especially the case for the $\mathrm{PM}_{10}$ fraction, which was found not correlating with any other PM size fraction of any site.

The temporal variability of the PM is presented in Fig. 11a. It should be noticed that the highest concentrations of $\mathrm{PM}_{1}$ were recorded between the 13 and 18 October, concomitant with the regional aerosol pollution described in Sect. 4.1. In particular, levels of $\mathrm{PM}_{1}$ were found to be enhanced in the TM site relative to the other sites, whereas the $\mathrm{PM}_{10}$ concentrations did not present such variation (Fig. 11a).

As regard of diurnal average concentrations (Fig. 11b), $\mathrm{PM}_{1}$ was found to vary little across the time of the day within the city centre, suggesting mainly a regional contribution and/or slow deposition, which maintains the particles constantly in the urban atmosphere although the emissions do vary throughout the day. By contrast, $\mathrm{PM}_{1}$ concentrations at the RB site were clearly dependent on the sea breeze circulation bringing pollution from the city during 
Table 6. Correlation table of aerosol mass loadings during SAPUSS. Correlations $\left(R^{2}\right)$ lower than 0.3 are omitted in this table.

\begin{tabular}{|c|c|c|c|c|c|c|c|c|c|c|c|c|c|c|c|c|c|c|}
\hline & $\begin{array}{r}\mathrm{TM} \\
\mathrm{PM}_{10}\end{array}$ & $\begin{array}{r}\mathrm{TM} \\
\mathrm{PM}_{2.5}\end{array}$ & $\begin{array}{r}\mathrm{TM} \\
\mathrm{PM}_{1}\end{array}$ & $\begin{array}{r}\mathrm{TC} \\
\mathrm{PM}_{10}\end{array}$ & $\begin{array}{r}\text { TC } \\
\mathrm{PM}_{2.5}\end{array}$ & $\begin{array}{r}\mathrm{TC} \\
\mathrm{PM}_{1}\end{array}$ & $\begin{array}{r}\mathrm{TCg} \\
\mathrm{PM}_{10}\end{array}$ & $\begin{array}{r}\mathrm{TCg} \\
\mathrm{PM}_{2.5}\end{array}$ & $\begin{array}{l}\mathrm{TCg} \\
\mathrm{PM}_{1}\end{array}$ & $\begin{array}{r}\mathrm{RS} \\
\mathrm{PM}_{10}\end{array}$ & $\begin{array}{r}\mathrm{RS} \\
\mathrm{PM}_{2.5}\end{array}$ & $\begin{array}{r}\mathrm{RS} \\
\mathrm{PM}_{1}\end{array}$ & $\begin{array}{r}\mathrm{UB} \\
\mathrm{PM}_{10}\end{array}$ & $\begin{array}{r}\text { UB } \\
\mathrm{PM}_{2.5}\end{array}$ & $\begin{array}{r}\text { UB } \\
\mathrm{PM}_{1}\end{array}$ & $\begin{array}{r}\mathrm{RB} \\
\mathrm{PM}_{10}\end{array}$ & $\begin{array}{r}\mathrm{RB} \\
\mathrm{PM}_{2.5}\end{array}$ & $\begin{array}{r}\mathrm{RB} \\
\mathrm{PM}_{1}\end{array}$ \\
\hline $\mathrm{TM}\left(\mathrm{PM}_{10}\right)$ & & 0.75 & 0.60 & & & & 0.50 & 0.55 & 0.55 & & 0.35 & 0.40 & 0.50 & 0.50 & 0.50 & & & 0.35 \\
\hline $\mathrm{TM}\left(\mathrm{PM}_{2.5}\right)$ & & & 0.95 & 0.50 & 0.40 & 0.40 & 0.70 & 0.85 & 0.85 & & 0.60 & 0.70 & 0.65 & 0.80 & 0.80 & & 0.35 & 0.40 \\
\hline $\mathrm{TM}\left(\mathrm{PM}_{1}\right)$ & & & & 0.40 & & 0.40 & 0.65 & 0.85 & 0.85 & & 0.55 & 0.75 & 0.55 & 0.75 & 0.85 & & & 0.40 \\
\hline $\mathrm{TC}\left(\mathrm{PM}_{10}\right)$ & & & & & 0.91 & 0.85 & 0.50 & 0.70 & 0.70 & & 0.56 & 0.55 & 0.40 & 0.60 & 0.50 & & & 0.40 \\
\hline $\mathrm{TC}\left(\mathrm{PM}_{2.5}\right)$ & & & & & & 0.95 & 0.40 & 0.75 & 0.75 & & 0.60 & 0.60 & & 0.60 & 0.50 & & 0.45 & 0.45 \\
\hline $\mathrm{TC}\left(\mathrm{PM}_{1}\right)$ & & & & & & & & 0.75 & 0.75 & & 0.60 & 0.60 & & 0.55 & 0.50 & & 0.42 & 0.45 \\
\hline $\mathrm{TCg}\left(\mathrm{PM}_{10}\right)$ & & & & & & & & 0.85 & 0.85 & & 0.75 & 0.75 & 0.70 & 0.75 & 0.70 & & 0.40 & 0.45 \\
\hline $\mathrm{TCg}\left(\mathrm{PM}_{2.5}\right)$ & & & & & & & & & 0.95 & & 0.80 & 0.85 & 0.70 & 0.85 & 0.90 & & 0.40 & 0.50 \\
\hline $\mathrm{TCg}\left(\mathrm{PM}_{1}\right)$ & & & & & & & & & & & 0.80 & 0.85 & 0.66 & 0.90 & 0.90 & & 0.40 & 0.50 \\
\hline $\mathrm{RS}\left(\mathrm{PM}_{10}\right)$ & & & & & & & & & & & 0.60 & 0.50 & 0.55 & & & & & \\
\hline $\mathrm{RS}\left(\mathrm{PM}_{2.5}\right)$ & & & & & & & & & & & & 0.95 & 0.50 & 0.60 & 0.50 & & & \\
\hline $\operatorname{RS}\left(\mathrm{PM}_{1}\right)$ & & & & & & & & & & & & & 0.45 & 0.60 & 0.60 & & & \\
\hline $\mathrm{UB}\left(\mathrm{PM}_{10}\right)$ & & & & & & & & & & & & & & 0.80 & 0.70 & & & \\
\hline $\mathrm{UB}\left(\mathrm{PM}_{2.5}\right)$ & & & & & & & & & & & & & & & 0.95 & & & 0.40 \\
\hline $\mathrm{UB}\left(\mathrm{PM}_{1}\right)$ & & & & & & & & & & & & & & & & & & 0.40 \\
\hline $\mathrm{RB}\left(\mathrm{PM}_{10}\right)$ & & & & & & & & & & & & & & & & & 0.80 & 0.65 \\
\hline $\mathrm{RB}\left(\mathrm{PM}_{2.5}\right)$ & & & & & & & & & & & & & & & & & & 0.90 \\
\hline $\mathrm{RB}\left(\mathrm{PM}_{1}\right)$ & & & & & & & & & & & & & & & & & & \\
\hline
\end{tabular}

the afternoon. The $\mathrm{PM}_{10}$ diurnal variation was influenced by traffic rush hour at all urban sites (RS, UB, TM), with the highest day-night differences found at the RS, probably reflecting the higher influence of dust resuspension at the traffic site (Fig. 11b).

In summary, the mass concentrations of fine $\left(\mathrm{PM}_{1}\right)$ and coarse $\left(\mathrm{PM}_{1-10}\right)$ aerosols were strongly dependent on the monitoring sites, with traffic hotspot distance and vertical profile being the two most important factors regulating their concentrations. As a case study, Fig. 11c shows two different meteorological regimes: regional conditions (Reg: stagnant regional air masses without accumulation of nitrate containing aerosols, 29-30 September 2010) and regional conditions with nitrate containing aerosols (Reg-Nit: stagnant regional air masses with accumulation of nitrate containing aerosols, 15-16 October 2010; see also Sect. 4.4.3). In order to report visually the main difference within the urban area of Barcelona, Fig. 11c reports only three urban monitoring sites: the urban tower (TM), the road site (RS) and the urban background (UB). $\mathrm{PM}_{10}$ concentrations levels do not show a clear variation within the monitoring sites. By contrast, when the fine $\left(\mathrm{PM}_{1}\right)$ and coarse $\left(\mathrm{PM}_{1-10}\right)$ fractions are separated, a sticking opposite trend can be seen in the vertical urban column: higher loadings of fine aerosol mass at the towel level (TM) but higher loadings of coarse aerosol mass at the ground levels (UB, RS). These trends confirm the necessity of a three-dimensional scale (such as the one used during SAPUSS) to get the full picture of the aerosol mass concentration dynamics in the urban atmosphere.

\subsubsection{Chemical analysis at the SAPUSS monitoring sites}

Table 7 reports average fine $\left(\mathrm{PM}_{1}\right)$, coarse $\left(\mathrm{PM}_{1-10}\right)$ and total $\mathrm{PM}_{10}$ (fine and coarse) chemical components concentrations measured during SAPUSS (standard IDAEA-CSIC off-line technique filter analysis; see Sect. 3.2.2 and Querol et al., 2001b) and grouped as follows: sulfate $\left(\mathrm{SO}_{4}^{2-}\right)$, nitrate $\left(\mathrm{NO}_{3}^{-}\right)$, ammonium $\left(\mathrm{NH}_{4}^{+}\right)$, organic matter $(\mathrm{OM})$, elemental carbon (EC), marine aerosols (sum of $\mathrm{Na}$ and $\mathrm{Cl}$ ), crustal aerosols (sum of $\mathrm{Al}_{2} \mathrm{O}_{3}, \mathrm{SiO}_{2}, \mathrm{CO}_{3}^{2-}, \mathrm{Ca}, \mathrm{Fe}, \mathrm{K}, \mathrm{Mg}, \mathrm{Mn}$, Ti and $\mathrm{P}$ - see Querol et al., 2001b), and the unaccounted mass. Overall, the SAPUSS monitoring sites presented different trends in average concentrations (Table 7). The main fine chemical component at the RS site was found to be OC, followed by sulfate and EC. By contrast, the coarse fraction was dominated by the crustal component. Relative to the average of other urban sites, this component presented a large increment $(76 \%)$ at the RS site, indicating road dust as a major source of PM in the road site environment. When the total (fine and coarse) $\mathrm{PM}_{10}$ fractions are considered, similar concentrations at the five monitoring sites for ammonium and sulfate can be seen, but higher levels of OC, EC and crustal aerosols were found at the RS. The background sites (TCg, $\mathrm{RB})$ presented overall similar concentrations for all different chemical components. Interestingly, levels of nitrate were found at a higher level at the TM and RS relative to the remaining three monitoring sites (UB, TCg and RB). Previous studies showed that the $\mathrm{NH}_{3}-\mathrm{HNO}_{3}-\mathrm{NH}_{4} \mathrm{NO}_{3}$ system is sufficiently dynamic to result in a considerable variability of $\mathrm{NH}_{4} \mathrm{NO}_{3}$ at urban level. Single particle measurements of nitrate aerosol showed two types of nitrate-rich particle with contrasting behaviours: nitrate regionally transported and nitrate formed locally (Dall'Osto et al., 2009). Additionally, the cooler temperatures and higher relative humidity on the tower level can shift the gas/aerosol equilibrium towards the aerosol phase (Harrison et al., 2012). Future SAPUSS receptor modelling studies will try to apportion the sources and the processes of nitrate occurring both horizontally and vertically in the Barcelona urban atmosphere.

As regard of on-line chemical analysis, future studies will present in this ACP SAPUSS special issue detailed chemical results obtained by the large varieties of chemical tracers. 




Fig. 11. Temporal trends (a) and diurnal variation of selected aerosol PMx mass (b) for all the SAPUSS studies. (c) represents selected case study periods: regional conditions (Reg: stagnant regional air masses without accumulation of nitrate containing aerosols, 29-30 September 2010) and regional conditions with nitrate (Reg-Nit: stagnant regional air masses with accumulation of nitrate containing aerosols, 15-16 October 2010). 
Table 7. Mean concentrations $\left[\mu \mathrm{g} \mathrm{m}^{-3}\right.$ ] of $12 \mathrm{~h}$ resolution measurements from filters of $\mathrm{OM}, \mathrm{EC}, \mathrm{SO}_{4}^{2-}, \mathrm{NO}_{3}^{-}, \mathrm{NH}_{4}^{+}$, crustal, marine, and unaccounted mass in $\mathrm{PM}_{1}, \mathrm{PM}_{1-10}$, and $\mathrm{PM}_{10}$ fractions at different SAPUSS monitoring sites (RS, UB, RB). Please note that only PM 10 concentrations are available for the the TM and $\mathrm{TCg}$ site.

\begin{tabular}{|c|c|c|c|c|c|c|c|c|c|c|c|}
\hline & \multicolumn{11}{|c|}{ SAPUSS monitoring site } \\
\hline & \multicolumn{3}{|c|}{$\mathrm{RS}$} & \multicolumn{3}{|c|}{ UB } & \multicolumn{3}{|c|}{$\mathrm{RB}$} & \multirow{2}{*}{$\begin{array}{r}\mathrm{TM} \\
\mathrm{PM}_{10} \\
\text { (tot.) }\end{array}$} & \multirow{2}{*}{$\begin{array}{r}\mathrm{TC} \\
\mathrm{PM}_{10} \\
\text { (tot.) }\end{array}$} \\
\hline & $\begin{array}{l}\mathrm{PM}_{1} \\
\text { (fine) }\end{array}$ & $\begin{array}{r}\mathrm{PM}_{1-10} \\
\text { (coarse) }\end{array}$ & $\begin{array}{r}\mathrm{PM}_{10} \\
\text { (tot.) }\end{array}$ & $\begin{array}{l}\mathrm{PM}_{1} \\
\text { (fine) }\end{array}$ & $\begin{array}{r}\mathrm{PM}_{1-10} \\
(\text { coarse })\end{array}$ & $\begin{array}{r}\mathrm{PM}_{10} \\
\text { (tot.) }\end{array}$ & $\begin{array}{c}\mathrm{PM}_{1} \\
\text { (fine) }\end{array}$ & $\begin{array}{r}\mathrm{PM}_{1-10} \\
\text { (coarse) }\end{array}$ & $\begin{array}{r}\mathrm{PM}_{10} \\
\text { (tot.) }\end{array}$ & & \\
\hline OC & 3.5 & 0.13 & 3.7 & 2.1 & 0.44 & 2.5 & 1.7 & 1.3 & 3 & 2.5 & 2.2 \\
\hline $\mathrm{EC}$ & 1.4 & 0.0 & 1.4 & 0.69 & 0.2 & 0.9 & 0.19 & 0.08 & 0.27 & 0.67 & 0.47 \\
\hline $\mathrm{SO}_{4}^{2-}$ & 2 & 0.74 & 2.8 & 1.8 & 1.0 & 2.8 & 1.5 & 0.87 & 2.3 & 2.7 & 2.30 \\
\hline $\mathrm{NO}_{3}^{-}$ & 0.64 & 1.9 & 2.6 & 0.46 & 1.7 & 2.2 & 0.15 & 1.4 & 1.5 & 2.4 & 1.6 \\
\hline $\mathrm{NH}_{4}^{+}$ & 0.78 & 0.12 & 0.9 & 0.61 & 0.09 & 0.7 & 0.46 & 0.16 & 0.63 & 0.69 & 0.50 \\
\hline Crustal & 0.38 & 5.2 & 5.5 & 0.63 & 3.4 & 4.1 & 0.17 & 2.5 & 2.7 & 3.7 & 3.2 \\
\hline Marine & 0.46 & 1.9 & 2.4 & 0.30 & 1.6 & 1.9 & 0.49 & 0.41 & 0.91 & 2.4 & 1.4 \\
\hline
\end{tabular}

This allows providing a better understanding of the implications of the chemical and physical processes affecting concentrations of $\mathrm{PM}_{\mathrm{x}}$ in the Mediterranean urban atmosphere. Both the AMS and ATOFMS simultaneously deployed during SAPUSS at the two super sites (four particle mass spectrometers in total) generated very large and fruitful datasets. The two ATOFMSs (see Sect. 3.2.1) deployed simultaneously during the SAPUSS successfully collected in real time 1042331 and 274974 single particle mass spectra at the RS and UB, respectively. About 20 different particle types were classified by the Art-2a clustering algorithm - some of which were found simultaneously at the two sites. Specifically, a particle type internally mixed with elemental carbon and nitrate was found mainly during the last part of the SAPUSS campaign. NaCl-containing particles were highly enhanced during windy Atlantic air masses, suggesting that the Atlantic long-range transport sea salt component is higher that the local marine influence. A variety of particle types internally mixed with organic nitrogen (including amines) found at higher concentrations at the road site and spiking in both day- and night-time. The two HR-ToF-AMSs recorded organic species as the most predominant one at both SAPUSS super sites (62\% and $54 \%$ at the RS and UB, respectively). The second most abundant species was found to be sulfate, but it showed higher concentration at the UB site (19\% and $27 \%$, at RS and UB, respectively). Smaller proportions were found for nitrate $(10 \%$ and $6.7 \%$, at RS and UB, respectively) and ammonium (8\% and $11 \%$, at RS and UB, respectively), whereas chloride made a small contribution at both sites $(<1 \%)$.

\subsection{Modelling}

The main goal of the results included here is not to provide a comprehensive evaluation of the model behaviour for all the pollutants, but to highlight the ability of the modelling system MM5-EMEP-CHIMERE to reproduce $\mathrm{PM}_{10}, \mathrm{PM}_{2.5}$ and $\mathrm{PM}_{1}$ levels during the SAPUSS field study when compared to measured concentrations of air pollutants in the different measuring points of the Barcelona Metropolitan Area. Figure 12 depicts the mean and $1 \mathrm{~h}$ maximum ground levels for these pollutants, and Table 8 indicates the evaluation results. A number of metrics were used to examine the model performance. The mean bias $(B)$ is a common metric used to quantify the departure between modelled and observed quantities; meanwhile the mean normalized bias (MNB) represents a useful measure of the overall over- or under-estimation by the model. The model generally underestimates the SAPUSS average PM concentration observed in the Barcelona Metropolitan Area ( $B$ generally ranging from -1 to $-10 \mu \mathrm{g} \mathrm{m}^{-3}$, with the largest biases appearing for $\mathrm{PM}_{10}$; MNB from -5 to $-48 \%$ ). The standard deviation, which provides an idea of the hourly variability of the measurements and simulations (essential to characterize the amplitude of the daily cycles of pollutants), is also somehow underestimated by the simulations, especially for $\mathrm{PM}_{1}$ except at the UB station. Hence, the measurements for SAPUSS will contribute to a better characterization of this intra-daily variability and to check why the amplitude of the daily cycle is not well captured generally by these models.

On the other hand, the results of the evaluation for $\mathrm{PM}_{10}$ (with lower biases compared to $\mathrm{PM}_{2.5}$ and $\mathrm{PM}_{1}$ ) indicate that the model performs accurately, taking into account that current CTM simulations underestimate the PM concentrations by $30-50 \%$, using the current knowledge about aerosol physics and chemistry (Vautard et al., 2005), which is the order of magnitude found for SAPUSS modelling results. If the results of the evaluation are compared to the skill scores of recent works for several models (e.g. Vautard et al., 2009; Pay et al., 2010; Baldasano et al., 2011, and references therein), the MM5-EMEP-CHIMERE modelling system exhibits consistent scores for PM (with mean values generally close to the observation biases on the order of $-20 \%$ 
Table 8. Results of the evaluation of the modelling system applied during the SAPUSS field campaign versus observations: observed mean (OM); model mean (MM); bias (B); mean normalized bias (MNB); observed standard deviation (OSD); model standard deviation (MSD); percentage bias of the standard deviation (PBSD).

\begin{tabular}{|c|c|c|c|c|c|c|c|}
\hline Monitoring site & $\mathrm{OM}\left(\mu \mathrm{g} \mathrm{m}^{-3}\right)$ & $\mathrm{MM}\left(\mu \mathrm{g} \mathrm{m}^{-3}\right)$ & $\mathrm{B}\left(\mu \mathrm{g} \mathrm{m}^{-3}\right)$ & MNB (\%) & OSD $\left(\mu \mathrm{g} \mathrm{m}^{-3}\right)$ & $\operatorname{MSD}\left(\mu \mathrm{g} \mathrm{m}^{-3}\right)$ & $\operatorname{PBSD}(\%)$ \\
\hline \multicolumn{8}{|c|}{$\mathrm{PM}_{10}$} \\
\hline $\mathrm{RS}$ & 34.37 & 22.09 & -12.28 & -35.75 & 16.01 & 12.09 & -24.47 \\
\hline TM & 26.19 & 16.05 & -10.14 & -38.72 & 13.39 & 13.18 & -1.60 \\
\hline UB & 27.67 & 20.12 & -7.55 & -27.29 & 11.23 & 8.56 & -23.78 \\
\hline $\mathrm{TCg}$ & 21.43 & 18.78 & -2.65 & -12.39 & 8.77 & 9.58 & 9.35 \\
\hline $\mathrm{TC}$ & 19.32 & 18.26 & -1.05 & -5.45 & 4.26 & 5.31 & 24.55 \\
\hline $\mathrm{RB}$ & 19.80 & 10.34 & -9.46 & -47.79 & 11.44 & 7.56 & -33.92 \\
\hline \multicolumn{8}{|c|}{$\mathrm{PM}_{2.5}$} \\
\hline $\mathrm{RS}$ & 20.55 & 13.93 & -6.62 & -32.23 & 8.09 & 7.13 & -11.81 \\
\hline $\mathrm{TM}$ & 19.35 & 11.88 & -7.47 & -38.59 & 9.65 & 6.45 & -33.13 \\
\hline UB & 17.75 & 14.21 & -3.54 & -19.96 & 8.57 & 6.95 & -18.88 \\
\hline $\mathrm{TCg}$ & 16.61 & 12.62 & -3.99 & -24.03 & 8.16 & 5.12 & -37.26 \\
\hline $\mathrm{TC}$ & 17.40 & 13.02 & -4.38 & -25.19 & 4.01 & 4.99 & 24.56 \\
\hline $\mathrm{RB}$ & 10.91 & 8.47 & -2.44 & -32.37 & 4.41 & 5.95 & 34.87 \\
\hline \multicolumn{8}{|c|}{$\mathrm{PM}_{1}$} \\
\hline $\mathrm{RS}$ & 17.99 & 10.90 & -7.09 & -35.42 & 7.47 & 5.77 & -22.73 \\
\hline TM & 16.15 & 10.04 & -6.11 & -37.85 & 8.64 & 6.47 & -25.11 \\
\hline UB & 13.23 & 10.09 & -3.14 & -23.73 & 4.62 & 6.03 & 30.50 \\
\hline $\mathrm{TCg}$ & 11.97 & 8.99 & -2.98 & -24.92 & 7.11 & 5.01 & -29.51 \\
\hline $\mathrm{TC}$ & 14.73 & 10.66 & -4.07 & -27.62 & 3.64 & 3.44 & -5.57 \\
\hline $\mathrm{RB}$ & 10.56 & 7.22 & -3.34 & -31.62 & 5.41 & 6.03 & 11.40 \\
\hline
\end{tabular}

to $-50 \%)$. Further studies with SAPUSS data will allow validating the aerosol composition and the ground levels of trace gases, needed for an accurate speciation of the emissions in the target area.

Table 8 also shows that errors for $\mathrm{PM}_{10}$ decrease following the direction coastline-inland. For instance, the MNB at the TM site, located by the coast, is around $-39 \%$; this MNB decreases to $-27 \%$ at the UB site and up to $5 \%$ at the TC site. Overall, $\mathrm{PM}_{10}$ is less underestimated than $\mathrm{PM}_{2.5}$ and $\mathrm{PM}_{1}$, especially in TC and TCg. Largest biases for $\mathrm{PM}_{10}$ are found at RB. This negative bias may be produced by an underestimation in the transport pattern. The high local contribution and the lack of transport of PM are associated with the short lifetime of this kind of particles in the atmosphere of CTMs as a consequence of the fast deposition implemented (Jiménez-Guerrero et al., 2011b). In this same sense, Ellemann and Covert (2009) report an over-prediction of geometric mean diameter by CTMs and that aerosol size distributions are shifted to a larger size compared with observations (and that is likely the reason why $\mathrm{PM}_{10}$ is generally less underestimated than $\mathrm{PM}_{2.5}$ and $\mathrm{PM}_{1}$ ). This fact may affect the fine PM predictions, which will increase if over-predictions of the geometric mean diameter are corrected. The information obtained from SAPUSS field measurements may play an important role for improving low-diameter PM modelling results in the target area.

Moreover, the inaccuracies in representing accumulation and transport patterns during this period of simulation covering SAPUSS field campaign could be the origin of these underpredictions. Some emission sources are also missing in the emission model, such as the re-suspension from soils and paved roads in urban areas (Lenschow et al., 2001; Pay et al., 2011), which may exert a limited influence on the PM levels in the area especially during the peak traffic hours. The underestimation of PM levels (mainly in the case of $\mathrm{PM}_{1}$ ) may be caused because of the average volume defined by the model horizontal grid spacing, which must be sufficiently small to allow the air quality to be reproduced accurately, especially on urban scales (Jiménez-Guerrero et al., 2008). It appears that a finer grid is important for addressing air pollution processes in urban areas, whereas for rural areas larger grids may be allowed, for example, to capture the nonlinearity of the chemical formation as a function of precursor concentrations.

In summary, Fig. 12 shows that the complex topography of the Barcelona urban area (the Llobregat Valley on the left, the Besòs Valley on the right and the Collserola hills on the top, Fig. 1a) does not allow a uniform dispersion of the atmospheric pollutants. Future SAPUSS-related modelling works 




Fig. 12. Mean (top row) and $1 \mathrm{~h}$ maximum (bottom row) ground-level concentrations of (from left to right) $\mathrm{PM}_{10}, \mathrm{PM}_{2.5}$ and $\mathrm{PM}_{1}$ modelled during the SAPUSS field campaign in the Barcelona Metropolitan Area. Levels are expressed in $\mu \mathrm{g} \mathrm{m}^{-3}$.

will deal with a number of studies, such as meteorological validation of the integrations, an improvement of the vertical distribution of aerosols and the dynamical transport of the model, assessment of the chemical composition of aerosol (focusing in the inclusion of new aerosols, such as BC), validation of both the mass and the particle number in different measurement points, etc. SAPUSS constitutes a valuable database for modellers to understand the processes behind the biases and typical errors of chemistry transport models.

\section{Conclusions}

The complex physical and chemical properties of air pollution require an array of instruments to try to cover the full picture of the source identification of air pollutants in the atmosphere. SAPUSS laid the foundation for providing relevant results to allow the identification of emission sources and their respective contribution to the air pollutants in ambient air of an urban Mediterranean coastal environment (Barcelona). This paper has aimed to present an overview of the six monitoring sites used during the SAPUSS: traffic hotspot road site (RS), two urban background sites (UB and $\mathrm{TCg}$ ), two towers sites (TM and TC) and a regional background site (RB). During the four weeks intensive field study, a number of different air masses were encountered: continental and marine polar and continental and marine tropical. Both the spatial vertical and horizontal distributions of air pollutants were investigated to better understand the complex interactions between these pollutants and different meteoro- logical variables, as well as their influence on air quality. High levels of traffic gaseous pollutants were measured at the urban ground monitoring sites, whereas layers of tropospheric ozone were recorded at tower levels (average ozone concentrations $80 \pm 25 \mu \mathrm{g} \mathrm{m}^{-3}$ ).

Aerosol mass and number concentrations measured simultaneously in three spatial dimensions during SAPUSS showed a complex relationship between traffic sources and urban and regional pollution events. The analysis of the particulate matter (PM) mass concentrations showed an enhancement of coarse particles $\left(\mathrm{PM}_{2.5-10}\right)$ at the urban ground level $(+64 \%)$ but of fine ones $\left(\mathrm{PM}_{1}\right)$ at urban tower level $(+28 \%)$, suggesting knotty dynamics of the sizeresolved PM mass at both horizontal and vertical levels of the study area. By using the current knowledge on aerosol physics and chemistry, preliminary modelling findings reveal an underestimation of the PM concentrations by $30-50 \%$. Hence, all the results shown in this study - as well as the ones contained in this ACP SAPUSS special issue - will be better modelled; in an attempt to reduce the need for fixed continuous monitoring sites, and also coverage of a wider urban area rather than a specific location where a monitoring site is located. More information on the SAPUSS measurements and their analysis can be found in this special issue.

Acknowledgements. This study was supported by FP7-PEOPLE2009-IEF, project number 254773, SAPUSS - Solving Aerosol Problems Using Synergistic Strategies (Marie Curie Actions Intra European Fellowships. Manuel Dall'Osto). This study was also supported by research projects from the D.G. de Calidad 
y Evaluación Ambiental (Spanish Ministry of the Environment) and the Plan Nacional de I+D (Spanish Ministry of Science and Innovation (CGL2010-19464 (VAMOS) and CSD2007-00067 (GRACCIE))), and the departments of Medi Ambient from the Generalitat de Catalunya and Diputació de Barcelona, who kindly supported data of gaseous pollutants. M. C. Minguillón was funded by JAE-Doc CSIC programme, co-funded by the European Social Fund (ESF). This work was also partially funded by Generalitat de Catalunya. Meteorological data were provided by the Servei Meteorològic de Catalunya and by the Department of Physics from the University of Barcelona. Finally, Santiago Castante (Mapfre Tower), Diego Garcia Talavera (Collserola tower) and Alfons Puertas (Secció de Meteorologia, Fabra Observatory) are also acknowledged.

Edited by: S. Decesari

\section{References}

Alier, M., van Drooge, B. L., Dall'Osto, M., Querol, X., Grimalt, J. O., and Tauler, R.: Source apportionment of submicron organic aerosol at an urban background and a road site in Barcelona, Spain, Atmos. Chem. Phys. Discuss., 13, 1116711211, doi:10.5194/acpd-13-11167-2013, 2013.

Amato, F., Pandolfi, M., Viana, M., Querol, X., Alastuey, A., and Moreno, T.: Spatial and chemical patterns of $\mathrm{PM}_{10}$ in road dust deposited in urban environment, Atmos. Environ., 43, 16501659, 2009.

Baldasano, J. M., Pay, M. T., Jorba, O., Gassó, S., and JiménezGuerrero, P.: An annual assessment of air quality with the CALIOPE modeling system over Spain, Sci. Total Environ., 409, 2163-2178, doi:10.1016/j.scitotenv.2011.01.041, 2011.

Beddows, D. C. S., Dall'Osto, M., and Harrison, R. M.: Cluster Analysis of Rural, Urban and Curbside Atmospheric Particle Size Data, Environ. Sci. Technol., 43, 4694-4700, 2009.

Benton, A. K., Langridge, J. M., Ball, S. M., Bloss, W. J., Dall'Osto, M., Nemitz, E., Harrison, R. M., and Jones, R. L.: Night-time chemistry above London: measurements of $\mathrm{NO}_{3}$ and $\mathrm{N}_{2} \mathrm{O}_{5}$ from the BT Tower, Atmos. Chem. Phys., 10, 9781-9795, doi:10.5194/acp-10-9781-2010, 2010.

Bessagnet, B., Hodzic, A., Vautard, R., Beekmann, M., Cheinet, S., Honore, C., Liousse, C., and Rouil, L.: Aerosol modeling with CHIMERE - Preliminary evaluation at the continental scale, Atmos. Environ., 38, 2803-2817, 2004.

Birch, M. E. and Cary, R. A.: Elemental carbon-based method for monitoring occupational exposures to particulate diesel exhaust, Aerosol. Sci. Tech., 25, 221-241, 1996.

Brown, S. S., Ryerson, T. B., Wollny, A. G., Brock, C. A., Peltier, R., Sullivan, A. P., Weber, R. J., Dubé, W. P., Trainer, M., Meagher, J. F., Fehsenfeld, F. C., and Ravishankara, A. R.: Variability in Nocturnal Nitrogen Oxide Processing and Its Role in Regional Air Quality, Science, 311, 67-70, 2006.

Cavalli, F., Viana, M., Yttri, K. E., Genberg, J., and Putaud, J.-P.: Toward a standardised thermal-optical protocol for measuring atmospheric organic and elemental carbon: the EUSAAR protocol, Atmos. Meas. Tech., 3, 79-89, doi:10.5194/amt-3-79-2010, 2010.

Chang, W., Bhave, P., Brown, S., Riemer, N., Stutz, J., and Dabdub, D.: Tropospheric $\mathrm{N}_{2} \mathrm{O}_{5}$ : A review of ambient measurements and model calculations, Aerosol Sci. Technol., 45, 655-685, 2011.

Chiari, M., Lucarelli, F., Mazzei, F., Nava, S., Paperetti, L., Prati, P., Valli, G., and Vecchi, R.: Characterization of airborne particulate matter in an industrial district near Florence by PIXE and PESA, X-Ray Spectrom., 34, 323-329, 2005.

Clapp, L. J. and Jenkin, M. E.: Analysis of the relationship between ambient levels of $\mathrm{O}_{3}, \mathrm{NO}_{2}$ and $\mathrm{NO}$ as a function of $\mathrm{NO}_{\mathrm{x}}$ in the UK, Atmos. Environ., 35, 6391-6405, 2001.

Dall'Osto, M., Harrison, R. M., Coe, H., Williams, P. I., and Allan, J. D.: Real time chemical characterization of local and regional nitrate aerosols, Atmos. Chem. Phys., 9, 3709-3720, doi:10.5194/acp-9-3709-2009, 2009.

Dall'Osto, M., Thorpe, A., Beddows, D. C. S., Harrison, R. M., Barlow, J. F., Dunbar, T., Williams, P. I., and Coe, H.: Remarkable dynamics of nanoparticles in the urban atmosphere, Atmos. Chem. Phys., 11, 6623-6637, doi:10.5194/acp-11-66232011, 2011.

Dall'Osto, M., Beddows, D. C. S., Pey, J., Rodriguez, S., Alastuey, A., Harrison, Roy M., and Querol, X.: Urban aerosol size distributions over the Mediterranean city of Barcelona, NE Spain, Atmos. Chem. Phys., 12, 10693-10707, doi:10.5194/acp-1210693-2012, 2012.

Dall'Osto, M., Querol, X., Alastuey, A., O’Dowd, C., Harrison, R. M., Wenger, J., and Gómez-Moreno, F. J.: On the spatial distribution and evolution of ultrafine particles in Barcelona, Atmos. Chem. Phys., 13, 741-759, doi:10.5194/acp-13-741-2013, 2013a.

Dall'Osto, M., Querol, X., Amato, F., Karanasiou, A., Lucarelli, F., Nava, S., Calzolai, G., and Chiari, M.: Hourly elemental concentrations in PM2.5 aerosols sampled simultaneously at urban background and road site during SAPUSS - diurnal variations and PMF receptor modelling, Atmos. Chem. Phys., 13, 43754392, doi:10.5194/acp-13-4375-2013, 2013b.

DeCarlo, P. F., Kimmel, J. R., Trimborn, A., Northway, M. J., Jayne, J. T., Aiken, A. C., Gonin, M., Fuhrer, K., Horvath, T., Docherty, K. S., Worsnop, D. R., and Jimenez, J. L.: Field-deployable, high-resolution, time-of-flight aerosol mass spectrometer, Anal. Chem., 78, 8281-8289, 2006.

de Foy, B., Varela, J. R., Molina, L. T., and Molina, M. J.: Rapid ventilation of the Mexico City basin and regional fate of the urban plume, Atmos. Chem. Phys., 6, 2321-2335, doi:10.5194/acp-6-2321-2006, 2006.

Derognat, C., Beekmann, M., Baeumle, M., Martin, D., and Schmidt, H.: Effect of biogenic volatile organic compound emissions on tropospheric chemistry during the Atmospheric Pollution over the Paris Area (ESQUIF) campaign in the Ile-deFrance region, J. Geophys. Res., 108, 8560, doi:10.1029/2001 JD001421, 2003.

Díaz-de-Quijano, M., Peñuelas, J., and Ribas, A.: Increasing interannual and altitudinal ozone mixing ratios in the Catalan Pyrenees, Atmos. Environ., 43, 6049-6057, 2009.

Draxler, R. R. and Rolph, G. D.: Hysplit (hybrid single-particle lagrangian integrated trajectory) model (http://www.Arl.Noaa. Gov/ready/hysplit4.Html), in, NOAA Air Resources Laboratory, Silver Spring, MD, USA, 2003.

Dudhia, J. A.: nonhydrostatic version of the Penn State NCAR mesoscale model: Validation tests and simulation of an Atlantic cyclone and cold front, Mon. Weather Rev., 121, 1493-1513, 1993. 
EEA: Reporting on Ambient Air Quality Assessment in the EU Member States 2008ETC/ACC Technical Paper 2010/11, December 2010.

Eeftens, M., Tsai, M., Ampe, C., Anwander, B., Beelen, R., Bellander, T., Cesaroni, G., Cirach, M., Cyrys, J., de Hoogh, C., de Nazelle, A., de Vocht, F., Declercq, C., Dedele, A., Eriksen, K. T., Galassi, C., Grazuleviciene, R., Grivas, G., Heinrich, J., Hoffmann, B., Iakovides, M., Ineichen, A., Katsouyanni, K., Korek, M., Kramer, U., Kuhlbusch, T., Lanki, T., Madsen, C., Meliefste, K., Molter, A., Mosler, G., Nieuwenhuijsen, M., Oldenwening, M., Pennanen, A. S., Probst-Hensch, N., Quass, U., Raaschou, Nielsen O., Ranzi, A., Stephanou, E. G., Sugiri, D., Udvardy, O., Vaskovi, E., Weinmayr, G., Brunekreef, B., and Hoek, G.: Spatial variation of $\mathrm{PM}_{2.5}, \mathrm{PM}_{10}, \mathrm{PM}_{2.5}$ absorbance and PMcoarse between and within 20 European study areas and the relationship with NO2 - Results of the ESCAPE project, Atmos. Environ., 62, 303-317, 2012.

Elleman, R. A. and Covert, D. S.: Aerosol size distribution modeling with the Community Multiscale Air Quality modeling system (CMAQ) in the Pacific Northwest: 1. model comparison to observations, J. Geophys. Res., 114, D11206, doi:10.1029/2008JD010791, 2009.

Escudero, M., Castillo, S., Querol, X., Avila, A., Alarcón, M., Viana, M. M., Alastuey, A., Cuevas, E., and Rodríguez, S.: Wet and dry African dust episodes over Eastern Spain, J. Geophys. Res., 110, 4731-4746, 2005.

Formenti, P., Prati, P., Zucchiatti, A., Lucarelli, F., and Mandó, P. A.: Aerosol study in the town of Genova with a PIXE analysis, Nucl. Instrum. Meth., 113, 359-362, 1996.

Gard, E., Mayer, J. E., Morrical, B. D., Dienes, T., Fergenson, D. P., and Prather, K. A.: Real-time analysis of individual atmospheric aerosol particles: Design and performance of a portable ATOFMS, Anal. Chem., 69, 4083-4091, 1997.

Gong, L., Lewicki, R., Griffin, R. J., Flynn, J. H., Lefer, B. L., and Tittel, F. K.: Atmospheric ammonia measurements in Houston, TX using an external-cavity quantum cascade laser-based sensor, Atmos. Chem. Phys., 11, 9721-9733, doi:10.5194/acp-11-97212011, 2011.

Grell, A. G., Dudhia, J., and Stauffer, D. R.: A description of the fifth-generation PennState/NCAR mesoscale model (MM5). NCAR Technical Note NCAR/TN-398+STR, Natl Cent Atmos Res, Boulder, Colorado, 138, 1994.

Harrison, R. M., Beddows, D. C. S., and Dall'Osto, M.: PMF Analysis of Wide-Range Particle Size Spectra Collected on a Major Highway, Environ. Sci. Technol., 45, 5522-5528, doi:10.1021/es2006622, 2011.

Harrison, R. M., Dall'Osto, M., Beddows, D. C. S., Thorpe, A. J., Bloss, W. J., Allan, J. D., Coe, H., Dorsey, J. R., Gallagher, M., Martin, C., Whitehead, J., Williams, P. I., Jones, R. L., Langridge, J. M., Benton, A. K., Ball, S. M., Langford, B., Hewitt, C. N., Davison, B., Martin, D., Petersson, K. F., Henshaw, S. J., White, I. R., Shallcross, D. E., Barlow, J. F., Dunbar, T., Davies, F., Nemitz, E., Phillips, G. J., Helfter, C., Di Marco, C. F., and Smith, S.: Atmospheric chemistry and physics in the atmosphere of a developed megacity (London): an overview of the REPARTEE experiment and its conclusions, Atmos. Chem. Phys., 12, 3065-3114, doi:10.5194/acp-12-3065-2012, 2012.

Heese, B., Flentje, H., Althausen, D., Ansmann, A., and Frey, S.: Ceilometer lidar comparison: backscatter coefficient retrieval and signal-to-noise ratio determination, Atmos. Meas. Tech., 3, 1763-1770, doi:10.5194/amt-3-1763-2010, 2010.

Hussein, T., Karppinen, A., Kukkonen, J., Härkönen, J., Aalto, P. P., Hämeri, K., Kerminen, V.-M., and Kulmala, M.: Meteorological dependence of size.fractionated number concentrations of urban aerosol particles, Atmos. Environ., 40, 1427-1440, 2006.

IPCC, 2007: Climate Change 2007: The Physical Science Basis. Contribution of Working Group I to the Fourth Assessment Report of the Intergovernmental Panel on Climate Change, edited by: Solomon, S., Qin, D., Manning, M., Chen, Z., Marquis, M., Averyt, K. B., Tignor, M., and Miller, H. L., Cambridge University Press, Cambridge, United Kingdom and New York, NY, USA, 996 pp., 2007.

Jimenez, P., Lelieveld, J., and Baldasano, J. M.: Multiscale modeling of air pollutants dynamics in the northwestern Mediterranean basin during a typical summertime episode, J. Geophys. Res., 111, D18306, doi:10.1029/2005JD006516, 2006.

Jiménez-Guerrero, P., Jorba, O., Baldasano, J. M., and Gassó, S.: The use of a modelling system as a tool for air quality management: Annual high-resolution simulations and evaluation, Sci. Total Environ., 390, 323-340, doi:10.1016/j.scitotenv.2007.10.025, 2008.

Jiménez-Guerrero, P., Gómez-Navarro, J. J., Jerez, S., LorentePlazas, R., García Valero, J. A., and Montávez, J. P.: Isolating the effects of climate change in the variation of secondary inorganic aerosols (SIA) in Europe for the 21st century (1991-2100), Atmos. Environ., 45, 1059-1063, doi:10.1016/j.atmosenv.2010.11.022, 2011a.

Jiménez-Guerrero, P., Jorba, O., Pay, M. T., Montávez, J. P., Jerez, S., Gómez-Navarro, J. J., and Baldasano, J. M.: Comparison of two different sea-salt aerosol schemes as implemented in air quality models applied to the Mediterranean Basin, Atmos. Chem. Phys., 11, 4833-4850, doi:10.5194/acp-11-4833-2011, $2011 b$.

Jorba, O., Perez, C., Rocadenbosch, F., and Baldasano, J.: Cluster Analysis of 4-Day Back Trajectories Arriving in the Barcelona Area (Spain) from 1997 to 2002, J. Appl. Meteorol., 43 887-901, 2004.

Kanakidou, M., Mihalopoulos, N., Kindap, T., Im, U., Vrekoussis, M., Gerasopoulos, E., Dermitzaki, E., Unal, A., Kocak, M., Markakis, K., Melas, D., Kouvarakis, G., Youssef, A. F., Richter, A., Hatzianastassiou, N., Hilboll, A., Ebojie, F., Wittrock, F., von Savigny, C., and Burrows, J. P.: Megacities as hot spots of air pollution in the East Mediterranean, Atmos. Environ., 45, 12231235, 2011.

Kesselmeier, J. and Staudt, M.: Biogenic volatile organic compounds (VOC): an overview on emission, physiology and ecology, J. Atmos. Chem., 33, 23-88, 1999.

Koçak, M., Mihalopoulos, N., and Kubilay, N.: Contributions of natural sources to high $\mathrm{PM}_{10}$ and $\mathrm{PM}_{2.5}$ events in the eastern Mediterranean, Atmos. Environ., 41, 3806-3818, 2008.

Koulouri, E., Saarikoski, S., Theodosi, C., Markaki, Z., Gerasopoulos, E., Kouvarakis, G., Makela, T., Hillamo, R., and Mihalopoulos, N.: Chemical composition and sources of fine and coarse aerosol particles in the Eastern Mediterranean, Atmos. Environ., 42, 6542-6550, 2008.

Kulmala, M., Asmi, A., Lappalainen, H. K., Baltensperger, U., Brenguier, J.-L., Facchini, M. C., Hansson, H.-C., Hov, Ø., O'Dowd, C. D., Pöschl, U., Wiedensohler, A., Boers, R., 
Boucher, O., de Leeuw, G., Denier van der Gon, H. A. C., Feichter, J., Krejci, R., Laj, P., Lihavainen, H., Lohmann, U., McFiggans, G., Mentel, T., Pilinis, C., Riipinen, I., Schulz, M., Stohl, A., Swietlicki, E., Vignati, E., Alves, C., Amann, M., Ammann, M., Arabas, S., Artaxo, P., Baars, H., Beddows, D. C. S., Bergström, R., Beukes, J. P., Bilde, M., Burkhart, J. F., Canonaco, F., Clegg, S. L., Coe, H., Crumeyrolle, S., D’Anna, B., Decesari, S., Gilardoni, S., Fischer, M., Fjaeraa, A. M., Fountoukis, C., George, C., Gomes, L., Halloran, P., Hamburger, T., Harrison, R. M., Herrmann, H., Hoffmann, T., Hoose, C., Hu, M., Hyvärinen, A., Hõrrak, U., Iinuma, Y., Iversen, T., Josipovic, M., Kanakidou, M., Kiendler-Scharr, A., Kirkevåg, A., Kiss, G., Klimont, Z., Kolmonen, P., Komppula, M., Kristjánsson, J.-E., Laakso, L., Laaksonen, A., Labonnote, L., Lanz, V. A., Lehtinen, K. E. J., Rizzo, L. V., Makkonen, R., Manninen, H. E., McMeeking, G., Merikanto, J., Minikin, A., Mirme, S., Morgan, W. T., Nemitz, E., O’Donnell, D., Panwar, T. S., Pawlowska, H., Petzold, A., Pienaar, J. J., Pio, C., Plass-Duelmer, C., Prévôt, A. S. H., Pryor, S., Reddington, C. L., Roberts, G., Rosenfeld, D., Schwarz, J., Seland, Ø., Sellegri, K., Shen, X. J., Shiraiwa, M., Siebert, H., Sierau, B., Simpson, D., Sun, J. Y., Topping, D., Tunved, P., Vaattovaara, P., Vakkari, V., Veefkind, J. P., Visschedijk, A., Vuollekoski, H., Vuolo, R., Wehner, B., Wildt, J., Woodward, S., Worsnop, D. R., van Zadelhoff, G.-J., Zardini, A. A., Zhang, K., van Zyl, P. G., Kerminen, V.-M., S Carslaw, K., and Pandis, S. N.: General overview: European Integrated project on Aerosol Cloud Climate and Air Quality interactions (EUCAARI) - integrating aerosol research from nano to global scales, Atmos. Chem. Phys., 11, 13061-13143, doi:10.5194/acp11-13061-2011, 2011.

Laskin, A., Laskin, J., and Nizkorodov, S. A.: Mass spectrometric approaches for chemical characterization of atmospheric aerosols: critical review of the most recent advances, Environ. Chem., 9, 163-189, 2012.

Lenschow, P., Abraham, H. J., Kutzner, K., Lutz, M., Preu, J. D., and Reichenbcher, W.: Some ideas about the sources of $\mathrm{PM}_{10}$, Atmos. Environ., 35, Supplement No. 1, S23, 2011.

Martucci, G., Milroy, C., and O'Dowd, C. D.: Detection of Cloud Base Height Using Jenoptik CHM15K and Vaisala CL31 Ceilometers, J. Atmos. Ocean. Tech., 27, 305-318, 2010.

Maxwell, J. A., Teesdale, W. J., and Campbell, J. L.: The Guelph PIXE package II. Nucl Instrum Meth, 95, 407-421, 1995.

McMurry, P. H.: A review of atmospheric aerosol measurements, Atmos. Environ., 34, 1959-1999, 2000.

Meng, Z. Y., Lin, W. L., Jiang, X. M., Yan, P., Wang, Y., Zhang, Y. M., Jia, X. F., and Yu, X. L.: Characteristics of atmospheric ammonia over Beijing, China, Atmos. Chem. Phys., 11, 61396151, doi:10.5194/acp-11-6139-2011, 2011.

Millan, M. M., Salvador, R., Mantilla, E., and Kallos, G.: Photooxidant dynamics in the Mediterranean Basin in summer: results from European research projects, J. Geophys. Res., 102, 88118823, doi:10.1029/96JD03610, 1997.

Millan, M., Mantilla, E., Salvador, R., Carratala, A., Sanz, M. J., Alonso, L., Gangoiti, G., and Navazo, M.: Ozone cycles in the western Mediterranean basin: interpretation of monitoring data in complex coastal terrain, J. Appl. Meteorol., 39, 487-508, 73$83,2000$.

Minguillón, M. C., Perron, N., Querol, X., Szidat, S., Fahrni, S. M., Alastuey, A., Jimenez, J. L., Mohr, C., Ortega, A. M., Day,
D. A., Lanz, V. A., Wacker, L., Reche, C., Cusack, M., Amato, F., Kiss, G., Hoffer, A., Decesari, S., Moretti, F., Hillamo, R., Teinilä, K., Seco, R., Peñuelas, J., Metzger, A., Schallhart, S., Müller, M., Hansel, A., Burkhart, J. F., Baltensperger, U., and Prévôt, A. S. H.: Fossil versus contemporary sources of fine elemental and organic carbonaceous particulate matter during the DAURE campaign in Northeast Spain, Atmos. Chem. Phys., 11, 12067-12084, doi:10.5194/acp-11-12067-2011, 2011.

Mohr, C., DeCarlo, P. F., Heringa, M. F., Chirico, R., Slowik, J. G., Richter, R., Reche, C., Alastuey, A., Querol, X., Seco, R., Peñuelas, J., Jiménez, J. L., Crippa, M., Zimmermann, R., Baltensperger, U., and Prévôt, A. S. H.: Identification and quantification of organic aerosol from cooking and other sources in Barcelona using aerosol mass spectrometer data, Atmos. Chem. Phys., 12, 1649-1665, doi:10.5194/acp-12-1649-2012, 2012.

Nenes, A., Pandis, S. N., and Pilinis, C. ISORROPIA: A new thermodynamic equilibrium model for multiphase multicomponent inorganic aerosols, Aquatic Geochemistry, 4, 123-152, 1998.

Pandolfi, M., Martucci, G., Querol, X., Alastuey, A., Wilsenack, F., Frey, S., O’Dowd, C. D., and Dall'Osto, M.: Continuous atmospheric boundary layer observations in the coastal urban area of Barcelona, Spain, Atmos. Chem. Phys. Discuss., 13, 345-377, doi:10.5194/acpd-13-345-2013, 2013.

Pay, M. T., Piot, M., Jorba, O., Gassó, S., Gonçalves, M., Basart, S., Dabdub, D., Jiménez-Guerrero, P., and Baldasano, J. M.: A full year evaluation of the CALIOPE-EU air quality modeling system over Europe for 2004, Atmos. Environ., 44, 3322-3342, 2010.

Pay, M. T., Jiménez-Guerrero, P., and Baldasano, J.: Implementation of resuspension from paved roads for the improvement of CALIOPE air quality system in Spain, Atmos. Environ., 45, 802807, 2011.

Pérez, C., Sicard, M., Jorba, O., Comeron, A., and Baldasano, J. M.: Summertime re-recirculations of air pollutants over the NorthEastern Iberian coast observed from systematic EARLINET lidar measurements in Barcelona, Atmos. Environ. 38, 3983-4000, 2004.

Pereza, C., Jimeneza, P., Jorbaa, O., Sicardb, M., and Baldasano, J. M.: Influence of the PBL scheme on highresolution photochemical simulations in an urban coastal area over the Western Mediterranean, Atmos. Environ., 40, 5274-5297, 2006.

Pey, J., Alastuey, A., and Querol, X.: Discriminating the regional and urban contributions in the North-Western Mediterranean: PM levels and composition, Atmos. Environ., 44, 1587-1596, 2010.

Pope, C. A. and Dockery, D. W.: Health effects of fine particulate air pollution: lines that connect, J. Air Waste Manage. Assoc., 56, 709-742, 2006.

Pratt, K. A. and Prather, K. A.: Mass Spectrometry of atmospheric aerosols - Recent developments \& applications, Part I: Off-line mass spectrometry techniques, Mass Spectrom. Rev., 31, 1-16, doi:10.1002/mas.20322, 2011a.

Pratt, K. A. and Prather, K. A.: Mass Spectrometry of atmospheric aerosols - Recent developments \& applications. Part II: On-line mass spectrometry techniques, Mass Spectrom. Rev., 31, 17-48, doi:10.1002/mas.20330, 2011 b.

Putaud, J. P., Van Dingenen, R., Alastuey, A., Bauer, H., Birmili, W., Cyrys, J., Flentje, H., Fuzzi, S., Gehrig, R., Hansson, H. C., Harrison, R. M., Herrmann, H., Hitzenberger, R., Huglin, C., Jones, A. M., Kasper-Giebl, A., Kiss, G., Kousa, A., Kuhlbusch, T. A. J., 
Loschau, G., Maenhaut, W., Molnar, A., Moreno, T., Pekkanen, J., Perrino, C., Pitz, M., Puxbaum, H., Querol, X., Rodriguez, S., Salma, I., Schwarz, J., Smolik, J., Schneider, J., Spindler, G., Ten Brink, H., Tursic, J., Viana, M., Wiedensohler, A., and Raes, F:. A European aerosol phenomenology - 3: physical and chemical characteristics of particulate matter from 60 rural, urban, and kerbside sites across Europe, Atmos. Environ., 44, 1308-1320, 2010.

Querol, X., Alastuey, A., Rodriguez, S., Plana, F., Ruiz, C. R., Cots, N., Massague, G., and Puig, O.: $\mathrm{PM}_{10}$ and $\mathrm{PM}_{2.5}$ source apportionment in the Barcelona metropolitan area, Catalonia, Spain, Atmos. Environ., 35, 6407-6419, 2001a.

Querol, X., Alastuey, A., Rodriguez, S., Plana, F., Mantilla, E., and Ruiz, C. R.: Monitoring of $\mathrm{PM}_{10}$ and $\mathrm{PM}_{2.5}$ around primary particulate anthropogenic emission sources. Atmos. Environ., 35, 845-858, 2001b.

Querol, X., Pey, J., Pandolfi, M., Alastuey, A., Cusack, M., Perez, N., Moreno, T., Viana, M., Mihalopoulos, N., Kallos, G., and Kleanthous S.: African dust contributions to mean ambient $\mathrm{PM}_{10}$ mass-levels across the Mediterranean Basin, Atmos. Environ., 43, 4266-4277, 2009.

Reche, C., Viana, M., Pandolfi, M., Alastuey, A., Moreno, T., Amato, F., Ripoll, A., and Querol, X.: Urban NH3 levels and sources in a Mediterranean environment, Atmos. Environ., 57, 153-164, 2012.

Reche, C., Querol, X., Alastuey, A., Viana, M., Pey, J., Moreno, T., Rodríguez, S., González, Y., Fernández-Camacho, R., de la Rosa, J., Dall'Osto, M., Prévôt, A. S. H., Hueglin, C., Harrison, R. M., and Quincey, P.: New considerations for PM, Black Carbon and particle number concentration for air quality monitoring across different European cities, Atmos. Chem. Phys., 11, 6207-6227, doi:10.5194/acp-11-6207-2011, 2011.

Rodríguez, S., Querol, X., Alastuey, A., and Mantilla, E.: Origin of high summer $\mathrm{PM}_{10}$ and TSP concentrations at rural sites in Eastern Spain, Atmos. Environ., 36, 3101-3112, 2002.

Rodríguez, S., Querol, X., Alastuey, A., Viana, M. M., and Mantilla, E.: Events affecting levels and seasonal evolution of airborne particulate matter concentrations in the Western Mediterranean, Environ. Sci. Technol., 37, 216-222, doi:10.1021/es020106p, 2003.

Rouil, L., Honore, C., Vautard, R., Beekmann, M., Bessagnet, B., Malherbe, L., Meleux, F., Dufour, A., Elichegaray, C., Flaud J.M., Menut, L., Martin, D., Peuch, A., Peuch, V.-H., and Poisson, N.: PREV'AIR, an operational forecasting and mapping system for air quality in Europe, B. Am. Meteorol. Soc., 90, 73-83, 2009.

Schmidt, H., Derognet, C., Vautard, R., and Beekmann, M.: A comparison of simulated and observed ozone mixing rations for the summer of 1998 in Western Europe, Atmos. Environ., 35, 62776297, 2001.

Seinfeld, J. H. and Pandis, S. N.: Atmospheric chemistry and physics. From air pollution to climate change, New York, Wiley, 1998.

Soriano, C., Baldasano, J. M., Buttler, W. T., and Moore, K.: Circulatory patterns of air pollutants within the Barcelona Air Basin in a summertime situation: lidar and numerical approaches, Bound.-Lay. Meteorol., 98, 33-55, 2001.
Stutz, J., Wong, K. W., Lawrence, L., Ziemba, L., Flynn, J. H., Rappenglück, B., and Lefer, B.: Nocturnal $\mathrm{NO}_{3}$ radical chemistry in Houston, TX, Atmos. Environ., 44, 4099-4106, doi:10.1016/j.atmosenv.2009.03.004, 2009.

Su, Y. X., Sipin, M. F., Furutani, H., and Prather, K. A.: Development and Characterization of an Aerosol Time-of-Flight Mass Spectrometer with Increased Detection Efficiency, Anal. Chem., 76, 712-719, 2004.

Tang, Y. S., Cape, J. N., and Sutton, M. A.: Development and types of passive samplers for monitoring atmospheric $\mathrm{NO}_{2}$ and $\mathrm{NH}_{3}$ concentrations, The Scientific World, 1, 513-529, 2001.

Toll, I. and Baldasano, J. M.: Modeling of photochemical air pollution in the Barcelona area with highly disaggregated anthropogenic and biogenic emissions, Atmos. Environ., 34, 30603084, 2001.

Tong, N. Y. O., Leung, D. Y. C., and Liu, C.-H.: A review on ozone evolution and its relationship with boundary layer characteristics in urban environments, Water Air Soil Pollut., 214, 13-36, 2011.

Vautard, R., Bessagnet, B., Chin, M., and Menut, L.: On the contribution of natural aeolian sources to particulate matter concentrations in Europe: Testing hypotheses with a modelling approach, Atmos. Environ., 39, 3291-3303, doi:10.1016/j.atmosenv.2005.01.051, 2005.

Vautard, R., Schaap, M., Bergström, R., Bessagnet, B., Brandt, J., Builtjes, P.J.H., Christensen, J.H., Cuvelier, C., Foltescu, V., Graff, A., Kerschbaumer, A., Krol, M., Roberts, P., Rouill, L., Stern, R., Tarrason, L., Thunis, P., Vignati, E., and Wind, P.: Skill and uncertainty of a regional air quality model ensemble, Atmos. Environ., 43, 4822-4832, doi:10.1016/j.atmosenv.2008.09.083, 2009.

Velchev, K., Cavalli, F., Hjorth, J., Marmer, E., Vignati, E., Dentener, F., and Raes, F.: Ozone over the Western Mediterranean Sea - results from two years of shipborne measurements, Atmos. Chem. Phys., 11, 675-688, doi:10.5194/acp-11-675-2011, 2011.

Vestreng, V., Ntziachristos, L., Semb, A., Reis, S., Isaksen, I. S. A., and Tarrasón, L.: Evolution of NOx emissions in Europe with focus on road transport control measures, Atmos. Chem. Phys., 9, 1503-1520, doi:10.5194/acp-9-1503-2009, 2009.

Viana, M., López, J. M., Querol, X., Alastuey, A., García-Gacio, D., Blanco-Heras, G., López-Mahía, P., Piñeiro- Iglesias, M., Sanz, M. J., Sanz, F., Chi, X., and Maenhaut, W.: Tracers and impact of open burning of rice straw residues on PM in Eastern Spain, Atmos. Environ., 42, 1941-1957, 2008.

Wong, K. W. and Stutz, J.: Influence of nocturnal vertical stability on daytime chemistry: A one-dimensional model study, Atmos. Environ., 44, 3753-3760, doi:10.1016/j.atmosenv.2010.06.057, 2010 . 